\title{
Power to Gas projects review: Lab, pilot and demo plants for storing renewable energy and $\mathrm{CO}_{2}$
}

\author{
Manuel BAILERA ${ }^{\mathrm{a}}$, Pilar LISBONA ${ }^{\mathrm{b}}$, Luis M. ROMEO ${ }^{\mathrm{c}}$, Sergio ESPATOLERO \\ ${ }^{a}$ Research Centre for Energy Resources and Consumption (CIRCE) - Universidad de Zaragoza, \\ CIRCE Building - Campus Río Ebro, Mariano Esquillor Gómez, 15, 50018 \\ Zaragoza, Spain \\ ${ }^{\text {b }}$ Escuela Universitaria de Ingenierías Agrarias de Soria - Universidad de Valladolid, \\ Campus Universitario Duques de Soria, 42004, Soria, Spain.

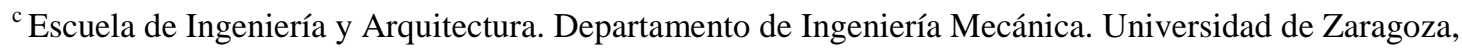 \\ Campus Río Ebro, María de Luna 3, 50018, Zaragoza, Spain.
}

\begin{abstract}
Power to Gas (PtG) processes have appeared in the last years as a long-term solution for renewable electricity surplus storage through methane production. These promising techniques will play a significant role in the future energy storage scenario since it addresses two crucial issues: electrical grid stability in scenarios with high share of renewable sources and decarbonisation of high energy density fuels for transportation. There are a large number of pathways for the transformation of energy from renewable sources into gaseous or liquid fuels through the combination with residual carbon dioxide. The high energy density of these synthetic fuels allows a share of the original renewable energy to be transported and stored in the long-term. The first objective of this review is to thoroughly gather and classify all these energy storage techniques to define in a clear manner the framework which includes the Power to Gas technologies.
\end{abstract}


Once the boundaries of these PtG processes have been evidenced, the second objective of the work is to detail worldwide existing projects which deal with this technology. Basic information such as main objectives, location and launching date is presented together with a qualitative description of the plant, technical data, funding source/budget and project partners. A timeline has been built for every project to be able of tracking the evolution of research lines of different companies and institutions.

\section{Keywords}

Power-to-Gas, Energy storage, Carbon capture, SNG

\section{Introduction}

One of the targets of renewable energy issues enclosed in the roadmap of the European Commission for 2020 is the achievement of a $20 \%$ of renewable energy in the overall energy mix of the European Union. In fact, renewables will continue to play a key role in helping the EU meet its energy needs beyond 2020 since EU countries have already agreed on a new renewable energy target of at least $27 \%$ of final energy consumption in the EU as a whole by 2030. Thus, renewable energy sources such as solar or wind will play a significant role in electric power generation. The last progress report towards the EU's 2020 renewable energy goals published in June 2015 presents an average share of the renewable electricity supply of $24 \%$ with strong differences among countries [1]. While countries as Malta has reached shares of renewable electricity production near 1\%; shares above $60 \%$ have already been reached in several European countries such as Sweden and Austria becoming in some cases the largest primary source of electricity $[2]$. 
Given the fluctuating and intermittent nature of these energy sources, mismatches between supply and electrical demand which affect to security and stability of the grid will appear. These mismatches must be balanced for grid stability purposes. This has become a critical challenge for future society which must be tackled by developing innovative energy storage solutions. Current storage systems present low energy density or limited storage potential. Therefore, new technologies must be developed to overcome these limitations and increase reserve production ratio.

A large number of pathways exist for the transformation of renewable energy into gaseous or liquid fuels through the combination with residual carbon dioxide. Up to now, a clear classification of these processes is not presented in literature. Thus, some confusion may appear when referring these new storage systems which convert solar energy or power from renewable into fuels. Among them, Power to Gas processes appear as promising systems which convert electricity into synthetic natural gas. The features of this technology allow the connection of electric and gas networks in a single energy system introducing high flexibility in the balance of the grid [3].

The first objective of this work is to outline a generalization of the PtG concept, thus giving to the reader a more structured understanding of what is behind these ideas. Since there exists a lack of detailed information in literature referred to this promising long-term electricity storage technique, the second objective of the review is to compile worldwide PtG projects specifications in a structured manner. Thus, we present a thorough review which gathers the construction and operation of pilot-, demo- and lab plants destined to the storage of electricity into SNG. 


\section{Hybrid storage of renewable energy and $\mathrm{CO}_{2}$}

The Power to Gas concept, storing renewable energy and carbon dioxide as natural gas, was first proposed by Koji Hashimoto in 1994 [4]. The difficulties associated to largedistance electricity transport in Japan inspired the research on energy carriers. The combination of electrolysis -run by solar energy- and the Sabatier reaction (Eq. (1)) allowed methane synthesis and the subsequent distribution of renewable electricity without the requirement of new infrastructures or alternative combustion systems. Moreover, as $\mathrm{CO}_{2}$ is recycled, the global warming would be mitigated in some extent $[5]$.

$$
\mathrm{CO}_{2}+4 \mathrm{H}_{2} \leftrightarrow \mathrm{CH}_{4}+2 \mathrm{H}_{2} \mathrm{O} \quad \Delta \mathrm{H}_{298 \mathrm{~K}}=-164.9 \mathrm{~kJ} / \mathrm{mol}
$$

In 2009, Michael Sterner refreshed the Power to Gas concept to focus on the storage of the increasing renewable power surplus, rather than on electricity transportation necessities. Several configurations were outlined depending on the carbon dioxide source used in the methanation stage (biogas, syngas or pure $\mathrm{CO}_{2}$ ) [3]. The simplest integration directly transforms $\mathrm{CO}_{2}$ from carbon capture techniques, e.g. postcombustion and oxyfuel combustion. Other possibility involves the methanation of biogas produced by anaerobic digestion of biomass or wastes. In this case, methanation may be carried out by directly adding hydrogen, since biogas is mainly composed by $\mathrm{CO}_{2}$ and $\mathrm{CH}_{4}$.

Traditionally, biogas had always been upgraded through the separation of both components to reject $\mathrm{CO}_{2}$ and obtain a purified stream of methane [6]. This option cannot be considered as a Power to Gas technique since it neither stores electricity nor makes use of the carbon dioxide obtained in the fermentation process. 
Similarly, Sterner proposed the upgrading of gasification syngas through the addition of renewable hydrogen -hydrogen obtained from renewable energy sources- as an alternative Power to Gas concept. Syngas is mainly composed by $\mathrm{CO}, \mathrm{CO}_{2}, \mathrm{CH}_{4}$ and $\mathrm{H}_{2}$, with specific volumetric fractions that significantly vary depending on the feedstock and the gasification process involved [7]. The hydrogen content is hardly ever enough to transform the whole amount of $\mathrm{CO}$ and $\mathrm{CO}_{2}$ through a stoichiometric Sabatier process. Hence, the addition of hydrogen would be required to achieve complete methanation of these compounds.

Obtaining synthetic natural gas (SNG) from coal gasification syngas reached a commercial stage of development in the 80/90's [8], while from biomass syngas recently reached the demonstration scale with a $20 \mathrm{MW}$ facility built in the framework of the GoBiGas project [9]. The $\mathrm{CO}: \mathrm{H}_{2}$ ratio of the syngas is commonly adjusted in a subsequent stage by means of water-gas shift reaction (Eq. (2)) without adding renewable $\mathrm{H}_{2}$, and later removing the remaining $\mathrm{CO}_{2}$ [10][11]. As stated for traditional biogas upgrading, this conventional syngas upgrading plants cannot be considered as Power to Gas concepts.

$$
\mathrm{CO}+\mathrm{H}_{2} \mathrm{O} \leftrightarrow \mathrm{CO}_{2}+\mathrm{H}_{2} \quad \Delta \mathrm{H}_{298 \mathrm{~K}}=-41.2 \mathrm{~kJ} / \mathrm{mol}
$$

The very first PtG concept was associated with water dissociation by means of electrolysers to directly generate hydrogen from an electric input. Hence, initial references to Power to Gas concept were only related to the production of $\mathrm{H}_{2}$ from renewable energy sources (i.e. Power to Hydrogen) [12]. Great efforts have been done worldwide to develop a hydrogen-based economy and it has been proven that its definitive deployment is limited, among others, by the requirement of larger hydrogen infrastructure and a well-established hydrogen market [13]. Thus, several researchers 
left behind the initial Power to Hydrogen concept and proposed new configurations focused on the generation of other gaseous fuels such as methane to take advantage from the natural gas infrastructure.

The proposed generalization of Power to Gas concept, inspired by the initial ideas of Hashimoto in 1994, involves the simultaneous storage of carbon dioxide and renewable energy surplus in the form of a valuable product. The classification of those techniques included under this definition is illustrated in Figure 1.

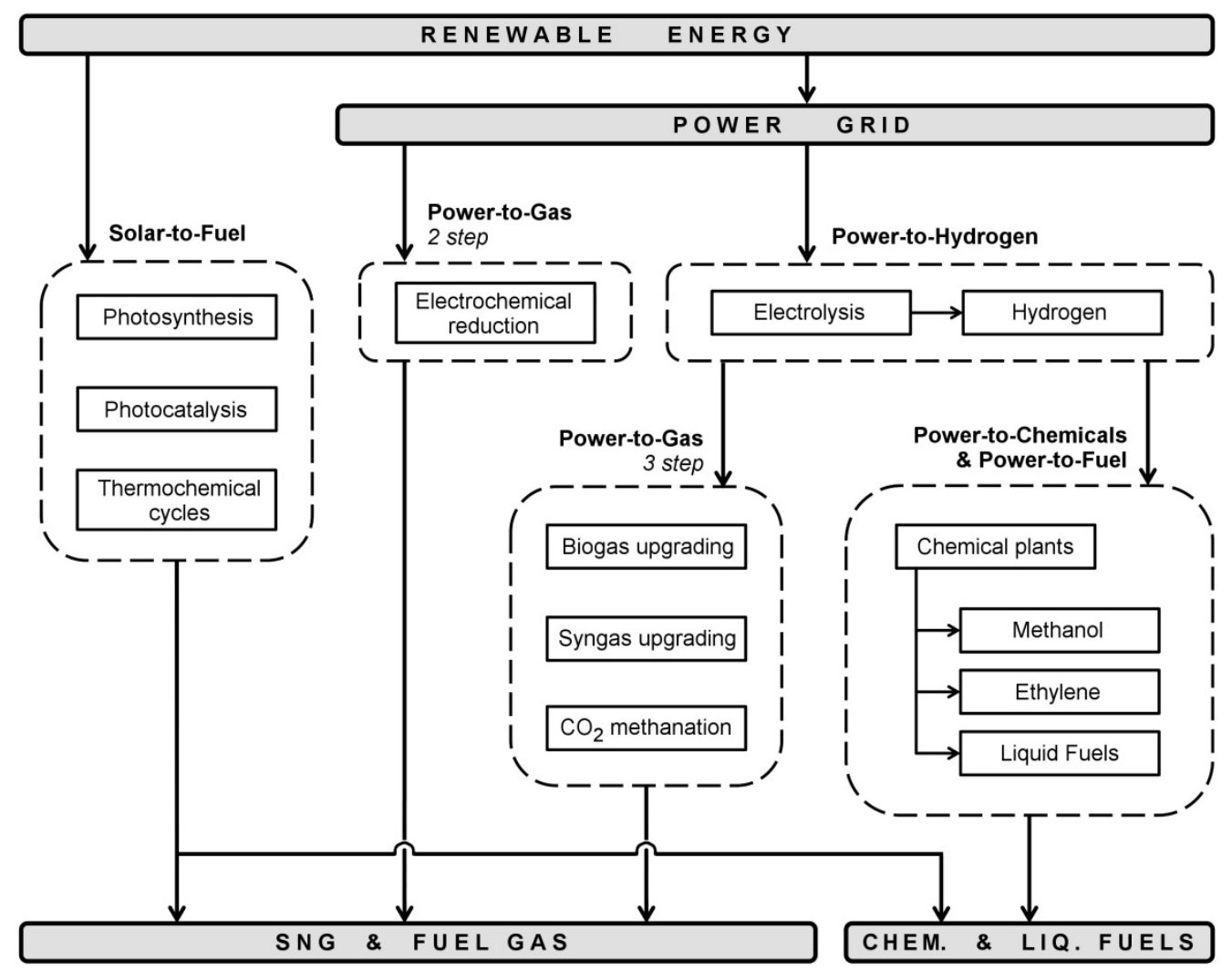

Figure 1. Renewable energy and $\mathrm{CO}_{2}$ hybrid storage techniques.

Chemical products that require hydrogen and carbon dioxide in their production process could also be considered as hybrid energy storage when $\mathrm{H}_{2}$ is renewably produced from surpluses. Some important chemicals in this field are methanol, ethylene, propylene, 
formic acid and liquid fuels [14]. They can directly use $\mathrm{CO}_{2}$, or convert the $\mathrm{CO}$ from a prior reverse water-gas shift reaction (reverse Eq. (2)).

Besides the commercial processes for the production of chemicals that can be converted into hybrid storage concepts, various novel processes under research would extend the term as well. They are grouped into 1-step or 2-step processes, depending on the number of stages required to transform renewable energy into final products [15].

The 1-step paths directly convert sunlight into valuable products, without an intermediate transformation into electricity. It is worthy to distinguish three of these storing processes also capable of consuming $\mathrm{CO}_{2}$ : i) photosynthesis-based metabolic routes, ii) photocatalysis and iii) thermochemical cycles.

Biological capture of $\mathrm{CO}_{2}$ fixes carbon and sunlight as chemical energy contained in newly grown organisms by means of photosynthesis. Since the efficiency of photosynthesis increases when generated organic structures present very small sizes, single-cell microalgae and cyanobacteria are the common options for this kind of process. Photons are absorbed by antenna proteins thus transferring their energy to the production of storage components, e.g., glucose, carbohydrates, lipids and proteins [16][17]. The development of biofuels from algal biomass is currently focused on addressing related environmental, technological and economic drawbacks, since the labscale phase has been completed successfully [18]. However, algae are already commercially applied in other non-energetic uses as pharmaceuticals [19][20], cosmetics [21][22] and animal feed [23][24]. Contrarily, biofuels from cyanobacteria are still far from its commercial development since greater efficiencies and improved reactor designs are needed [25][26]. 
In photocatalysis, as in electrochemical processes, carbon dioxide is reduced by means of an electric current. The difference between both techniques is the nature of the electrons that produce the electricity, since photocatalysis is generated by the absorption of a photon in semiconductor materials, thus producing a current based in electron-hole pairs [16]. $\mathrm{CO}_{2}$ photocatalysis is still not feasible due to the absence of scalable reactors able to produced significant quantities of fuel [27].

Thermochemical cycles reduce metal oxide materials (Eq. (3)) inside cavity receivers in concentrating solar plants at high temperatures $\left(1200-1600{ }^{\circ} \mathrm{C}\right)$. Later, when the metal oxide is regenerated by oxidation with carbon dioxide, it is obtained a syngas mainly composed of CO that can be methanized (Eq. (4)) [28][29]. The technique has been already successfully demonstrated at bench- and pilot-scale, but some crucial technical challenges remain unsolved for its commercial exploitation [30].

$$
\begin{gathered}
\mathrm{MO}_{2} \rightarrow \mathrm{MO}_{2-\delta}+\frac{\delta}{2} \mathrm{O}_{2}(\mathrm{~g}) \\
\delta \mathrm{CO}_{2}(\mathrm{~g})+\mathrm{MO}_{2-\delta} \rightarrow \mathrm{MO}_{2}+\delta \mathrm{CO}(\mathrm{g})
\end{gathered}
$$

The 2-step method involves the electrochemical reduction, where electrical energy is supplied to establish a potential between two electrodes in order to allow $\mathrm{CO}_{2}$ to be transformed into reduced forms [31]. Hence, renewable energy must be previously converted to electricity and later to the valuable chemical. Some of the most interesting products that could be included in the scheme through this method are formic acid, methanol and methane, which are produced by two-, six- and eight-electron reduction pathways, respectively [32]. However significant improvements in energy efficiency are needed before this technique becomes cost effective, in comparison with the current ways to produce the same products [33]. 
A large number of reviews have been published so far in reference to the development of these conversion paths studying different aspects (Table 1). However, none of them is focused on 3step-Power to Gas plants and their future perspectives. Therefore, the main objective of the present review is to gather those research projects concerning the construction or management of pilot- and demonstration plants which carry out 3stepPower to Gas paths, thus summarizing the state of the art of the technology. 
Table 1. Summary of selected reviews of renewable energy and $\mathrm{CO}_{2}$ hybrid storage techniques (2010 onwards).

\begin{tabular}{|c|c|c|}
\hline Review & Path & Focus \\
\hline Bennamoun, 2015 [34] & Photosynthesis & Drying methods for algae \\
\hline Bharathiraja, 2015 [35] & Photosynthesis & Algae cultivation methods and processing technologies \\
\hline Chen, 2015 [36] & Photosynthesis & Microalgae productivity and influencing factors toward biofuel production \\
\hline Sarsekeyeva, 2015 [37] & Photosynthesis & Developments of biofuels produced from cyanobacteria \\
\hline Song, 2015 [38] & Photosynthesis & Feature and applications of brown algae \\
\hline Sutherland, 2015 [39] & Photosynthesis & Limitations and improvements of algae in light absorption and utilization \\
\hline Trentacoste, 2015 [40] & Photosynthesis & Policies for algae cultivation \\
\hline Vijayakumar, 2015 [41] & Photosynthesis & Potential pharmaceutical applications of cyanobacteria \\
\hline Han, 2014 [42] & Photosynthesis & Algae waste composting \\
\hline Chow, 2013 [43] & Photosynthesis & Thermal chemical transformation of algae to biofuels \\
\hline Razzak, 2013 [44] & Photosynthesis & Microalgae culturing for $\mathrm{CO}_{2}$ capture, waste-water treatment and biofuel production \\
\hline Menetrez, 2012 [45] & Photosynthesis & Environmental impact issues of algae \\
\hline Rosgaard, 2012 [46] & Photosynthesis & Genetic engineering for improving carbon fixation in cyanobacteria \\
\hline Quadrelli, 2011 [14] & $\begin{array}{l}\text { Photosynthesis } \\
\text { Power to Chemicals }\end{array}$ & Large-volume routes for chemical utilization of $\mathrm{CO}_{2}$ at preindustrial level \\
\hline Brennan, 2010 [47] & Photosynthesis & Algae production, harvesting and conversion to fuel \\
\hline Kunjapur, 2010 [48] & Photosynthesis & Large-scale reactors used to cultivate microalgae for biofuel production \\
\hline Mata, 2010 [49] & Photosynthesis & Production and processing of microalgae for biodiesel production \\
\hline Ola, 2015 [27] & Photocatalysis & Reduction by $\mathrm{TiO}_{2}$ photocatalyst. Material design and reactor configurations \\
\hline
\end{tabular}




\begin{tabular}{|c|c|c|}
\hline Das, 2014 [50] & Photocatalysis & Photocatalysts and reactor systems for $\mathrm{CO}_{2}$ transformation into fuels \\
\hline Li, 2014 [51] & Photocatalysis & Material design and reactor engineering \\
\hline Liu, 2014 [52] & Photocatalysis & Reduction with $\mathrm{H}_{2} \mathrm{O}$ by $\mathrm{TiO}_{2}$ photocatalyst \\
\hline Sun, 2014 [53] & Photocatalysis & Reduction by nanostructured carbon catalyst \\
\hline Habisreutinger, 2013 [54] & Photocatalysis & Heterogeneous reduction by metal oxides, oxynitrides, sulphides and phosphides \\
\hline Izumi, 2013 [55] & Photocatalysis & Photocatalysis with water, hydrogen and recycling electron donors \\
\hline Tahir, 2013 [56] & Photocatalysis & Developments and applications of visible light responsive $\mathrm{TiO}_{2}$ photocatalysts \\
\hline Ganesh, 2011 [57] & Photocatalysis & Reduction to Methanol \\
\hline Agrafiotis, 2015 [30] & Thermochemical cycles & Types of cycles, heat transfer issues and reactors employed \\
\hline Scheffe, 2014 [58] & Thermochemical cycles & Comparison of physical properties between metal oxide materials \\
\hline Roeb, 2012 [59] & Thermochemical cycles & Reactor technologies and material properties regarding its technical implementation \\
\hline Loutzenhiser, 2010 [60] & Thermochemical cycles & Kinetics, reactor technology and economics for $\mathrm{Zn} / \mathrm{ZnO}$ cycles \\
\hline Albo, 2015 [31] & Electrochemical reduction & Reduction to methanol. Cathode materials, reaction media, cells and working conditions \\
\hline Jones, 2014 [61] & Electrochemical reduction & Comparison between methods \\
\hline Lim, 2014 [62] & Electrochemical reduction & SOFC, metal electrodes in aqueous solution and molecular catalysts \\
\hline Qiao, 2014 [32] & Electrochemical reduction & Catalysts for the reduction to low-carbon fuels \\
\hline Costentin, 2013 [63] & Electrochemical reduction & Comparison of performances between catalysts \\
\hline Jhong, 2013 [64] & Electrochemical reduction & Current status and remaining challenges \\
\hline Kondratenko, 2013 [65] & $\begin{array}{l}\text { Electrochemical reduction } \\
\text { Photocatalysis }\end{array}$ & Design of metal electrodes and alternative approaches \\
\hline Rittman, 2015 [66] & Biogas upgrading & Scale-up issues for biological $\mathrm{CH}_{4}$ production \\
\hline Götz, 2016 [67] & Biogas upgrading & Technological and economic issues of Power-to-Methane \\
\hline
\end{tabular}




\begin{tabular}{|l|l|l|}
\hline & $\begin{array}{l}\text { Syngas upgrading } \\
\mathrm{CO}_{2} \text { methanation }\end{array}$ & \\
\hline Rönsch, 2016 [68] & $\begin{array}{l}\text { Biogas upgrading } \\
\text { Syngas upgrading } \\
\mathrm{CO}_{2} \text { methanation }\end{array}$ & Methanation fundamentals (catalysts, mechanisms and modelling) and reactor concepts \\
\hline Aziz, 2015 [69] & Power-to-Chemicals & Reaction mechanism over heterogeneous catalysts \\
\hline Gao, 2015 [70] & Power-to-Chemicals & Methanation catalysts research and development \\
\hline Wang, 2011 [71] & Power-to-Chemicals & Catalytic reactivity and reaction mechanisms over heterogeneous catalysts \\
\hline Ganesh, 2014 [72] & $\begin{array}{l}\text { Power-to-Fuel } \\
\text { Solar-to-Fuel }\end{array}$ & Conversion of $\mathrm{CO}_{2}$ into methanol using any renewable energy source \\
\hline
\end{tabular}




\section{Review of Power to Gas (3 step) projects}

In this section a thorough review of 3step-Power to Gas projects which investigate methanation through the application of renewable hydrogen (at least in the conception of the system) is presented.

As a preliminary overview of the information presented in the following subsections, Figure 2 shows the distribution of the number of projects among countries classified by type of methanation process. Germany is the spearhead nation in developing PtG systems, mainly focused on $\mathrm{CO}_{2}$ catalytic methanation.

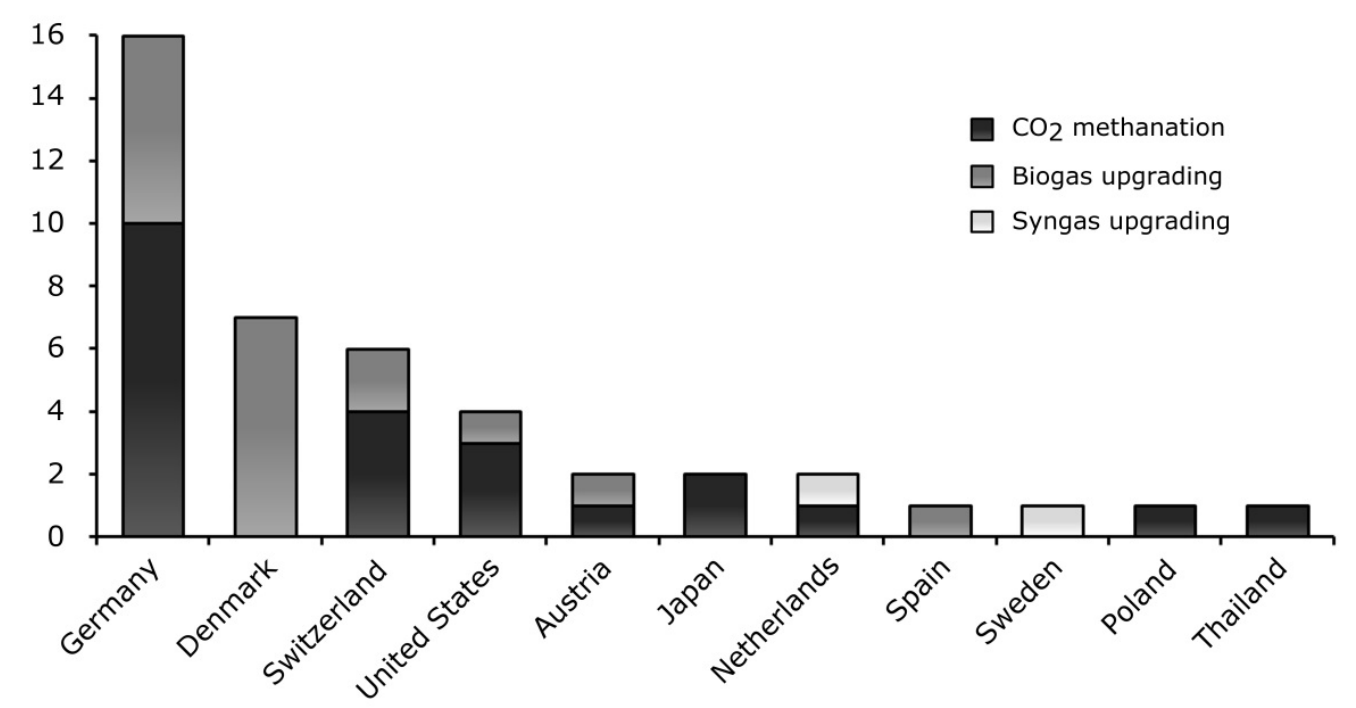

Figure 2. Existing PtG projects distributed by country and technology.

A timeline is built to clearly represent the evolution and concatenation of worldwide PtG projects with years, Figure 3. Tohoku University and Hitachi Zosen which initiated their research in PtG systems in 1996 appear as pioneers in this field. As shown in Figure 3, most of the projects were launched from 2009 onwards when the international 
community massively discovered the great potential of PtG in excess electricity storage.

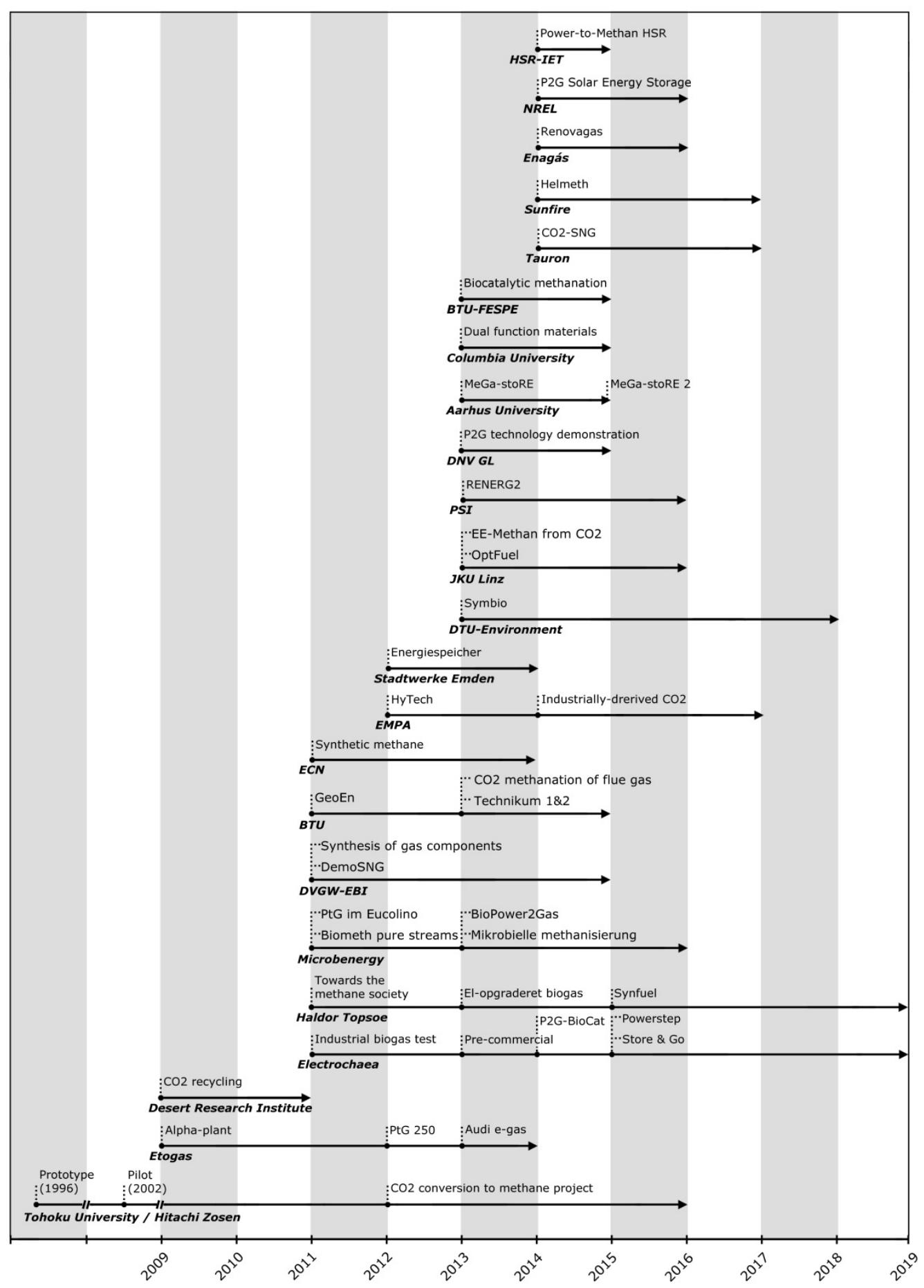

Figure 3. Timeline of worldwide existing PtG projects. 
General information of 3step-Power to Gas projects is summarized in Table 2, where related projects which imply an extension of a previous one are grouped in a samecolour block in order to historically follow the evolution of PtG technology.

Table 2. 3step-Power to Gas projects.

\begin{tabular}{|c|c|c|c|c|c|}
\hline $\begin{array}{l}\text { Process } \\
\text { type }\end{array}$ & Project Name & Location & Period & Institutions & Ref. \\
\hline $\begin{array}{l}\mathrm{CO}_{2} \\
\text { methanation }\end{array}$ & Audi e-gas & $\begin{array}{l}\text { Werlte, } \\
\text { Germany }\end{array}$ & 2013 & $\begin{array}{l}\text { ETOGAS, } \\
\text { ZSW, } \\
\text { Fraunhofer } \\
\text { IWES, EWE } \\
\text { Biogas, Audi }\end{array}$ & [74], [77] \\
\hline $\begin{array}{l}\mathrm{CO}_{2} \\
\text { methanation }\end{array}$ & Power to Gas 250 & $\begin{array}{l}\text { Stuttgart, } \\
\text { Germany }\end{array}$ & $\begin{array}{l}2012- \\
2014\end{array}$ & $\begin{array}{l}\text { ETOGAS, } \\
\text { ZSW, } \\
\text { Fraunhofer } \\
\text { IWES }\end{array}$ & [84] \\
\hline $\begin{array}{l}\text { Biogas } \\
\text { upgrading }\end{array}$ & Alpha-plant & $\begin{array}{l}\text { Bad } \\
\text { Hersfeld, } \\
\text { Germany }\end{array}$ & 2012 & $\begin{array}{l}\text { ETOGAS, } \\
\text { ZSW, } \\
\text { Fraunhofer } \\
\text { IWES, HBFZ }\end{array}$ & [87] \\
\hline $\begin{array}{l}\text { Biogas } \\
\text { upgrading }\end{array}$ & Alpha-plant & $\begin{array}{l}\text { Morbach, } \\
\text { Germany }\end{array}$ & 2011 & $\begin{array}{l}\text { ETOGAS, } \\
\text { ZSW, } \\
\text { Fraunhofer } \\
\text { IWES, Juwi }\end{array}$ & [85], [86] \\
\hline $\begin{array}{l}\mathrm{CO}_{2} \\
\text { methanation }\end{array}$ & Alpha-plant & $\begin{array}{l}\text { Werlte, } \\
\text { Germany }\end{array}$ & $\begin{array}{l}2010- \\
2011\end{array}$ & $\begin{array}{l}\text { ETOGAS, } \\
\text { ZSW, EWE } \\
\text { Biogas }\end{array}$ & [85] \\
\hline $\begin{array}{l}\mathrm{CO}_{2} \\
\text { methanation }\end{array}$ & Alpha-plant & $\begin{array}{l}\text { Stuttgart, } \\
\text { Germany }\end{array}$ & 2009 & ETOGAS, ZSW & [83] \\
\hline n/a & STORE \& GO & $\begin{array}{l}\text { Switzerland, } \\
\text { Germany, } \\
\text { Italy }\end{array}$ & $\begin{array}{l}2015- \\
2019\end{array}$ & $\begin{array}{l}\text { Electrochaea, } \\
\text { DVGW, E.ON, } \\
\text { Regio Energie, } \\
\text { EII Spa, HSR, } \\
\text { PoliTo, JKU } \\
\text { Linz-EI, RUG, } \\
\text { Atmostat, CEA, } \\
\text { Clmeworks, } \\
\text { DBI-GUT, BFP, } \\
\text { EDI, EMPA, } \\
\text { EPFL-IPESE, } \\
\text { EPFL-MER, } \\
\text { EPFL-CEN, } \\
\text { Energy Valley }\end{array}$ & [98], [106] \\
\hline $\begin{array}{l}\text { Biogas } \\
\text { upgrading }\end{array}$ & $\begin{array}{l}\text { POWERSTEP - Full } \\
\text { scale demonstration } \\
\text { of energy positive }\end{array}$ & n/a & $\begin{array}{l}2015- \\
2018\end{array}$ & $\begin{array}{l}\text { Electrochaea, } \\
\text { KWB, TU } \\
\text { Wien, Eawag, }\end{array}$ & $\begin{array}{l}\text { [97], [104], } \\
{[105]}\end{array}$ \\
\hline
\end{tabular}




\begin{tabular}{|c|c|c|c|c|c|}
\hline & $\begin{array}{l}\text { sewage treatment } \\
\text { plant concepts } \\
\text { towards market } \\
\text { penetration }\end{array}$ & & & $\begin{array}{l}\text { Fraunhofer } \\
\text { IPM, Veolia, } \\
\text { Veolia-WT, } \\
\text { NEAS, Biofos, } \\
\text { BWB, UBA, } \\
\text { APS, Sustec, } \\
\text { Atemis, Arctik }\end{array}$ & \\
\hline $\begin{array}{l}\text { Biogas } \\
\text { upgrading }\end{array}$ & P2G-BioCat project & $\begin{array}{l}\text { Avedøre, } \\
\text { Denmark }\end{array}$ & $\begin{array}{l}2014- \\
2016\end{array}$ & $\begin{array}{l}\text { Electrochaea, } \\
\text { Hydrogenics, } \\
\text { Audi, NEAS, } \\
\text { HMN } \\
\text { Gashandel, } \\
\text { Biofos, Insero }\end{array}$ & $\begin{array}{l}{[90],[94],} \\
{[96]}\end{array}$ \\
\hline $\begin{array}{l}\text { Biogas } \\
\text { upgrading }\end{array}$ & Pre-commercial & $\begin{array}{l}\text { Foulum, } \\
\text { Denmark }\end{array}$ & 2013 & $\begin{array}{l}\text { Electrochaea, } \\
\text { E.ON, Energie } \\
360^{\circ} \text {, EWZ, } \\
\text { NEAS, AU }\end{array}$ & [100], [102] \\
\hline $\begin{array}{l}\text { Biogas } \\
\text { upgrading }\end{array}$ & Industrial Biogas Test & $\begin{array}{l}\text { Chicago, } \\
\text { United States }\end{array}$ & 2011 & $\begin{array}{l}\text { Electrochaea, } \\
\text { UChicago, AB } \\
\text { InBev }\end{array}$ & [99], [100] \\
\hline $\begin{array}{l}\text { Biogas } \\
\text { upgrading }\end{array}$ & BioPower2Gas & $\begin{array}{l}\text { Allendorf, } \\
\text { Germany }\end{array}$ & $\begin{array}{l}2013- \\
2016\end{array}$ & $\begin{array}{l}\text { Microbenergy, } \\
\text { Schmack, } \\
\text { Carbotech, } \\
\text { EnergieNetz, } \\
\text { EAM } \\
\text { EnergiePlus, } \\
\text { CUBE, DBFZ, } \\
\text { IdE }\end{array}$ & $\begin{array}{l}\text { [107], [108], } \\
\text { [109] }\end{array}$ \\
\hline $\begin{array}{l}\text { Biogas } \\
\text { upgrading }\end{array}$ & $\begin{array}{l}\text { Mikrobielle } \\
\text { Methanisierung }\end{array}$ & $\begin{array}{l}\text { Schwandorf, } \\
\text { Germany }\end{array}$ & 2013 & $\begin{array}{l}\text { Microbenergy, } \\
\text { Schmack, } \\
\text { FENES, } \\
\text { ZVKSW }\end{array}$ & [114], [115] \\
\hline $\begin{array}{l}\text { Biogas } \\
\text { upgrading }\end{array}$ & $\begin{array}{l}\text { Power-to-Gas im } \\
\text { Eucolino }\end{array}$ & $\begin{array}{l}\text { Schwandorf, } \\
\text { Germany }\end{array}$ & 2011 & $\begin{array}{l}\text { Microbenergy, } \\
\text { Schmack }\end{array}$ & [73], [112] \\
\hline $\begin{array}{l}\mathrm{CO}_{2} \\
\text { methanation }\end{array}$ & $\begin{array}{l}\text { Biological } \\
\text { methanation of pure } \\
\text { streams }\end{array}$ & $\begin{array}{l}\text { Schwandorf, } \\
\text { Germany }\end{array}$ & 2011 & $\begin{array}{l}\text { Microbenergy, } \\
\text { Schmack }\end{array}$ & {$[73]$} \\
\hline $\begin{array}{l}\mathrm{CO}_{2} \\
\text { methanation }\end{array}$ & HELMETH & $\mathrm{n} / \mathrm{a}$ & $\begin{array}{l}2014- \\
2017\end{array}$ & $\begin{array}{l}\text { Sunfire, KIT, } \\
\text { PoliTo, ERIC, } \\
\text { TS-Torino, } \\
\text { NTUA, DVGW }\end{array}$ & [116], [123] \\
\hline $\begin{array}{l}\text { Syngas } \\
\text { upgrading }\end{array}$ & SYNFUEL & $\mathrm{n} / \mathrm{a}$ & $\begin{array}{l}2015- \\
2019\end{array}$ & $\begin{array}{l}\text { Haldor Topsoe, } \\
\text { DTU, AAU, } \\
\text { Chalmers, } \\
\text { DONG, } \\
\text { Energinet.dk, } \\
\text { INSA, TU } \\
\text { Berlin, NU, } \\
\text { CAS, MIT, } \\
\text { AVL }\end{array}$ & [137] \\
\hline Biogas & El-opgraderet biogas & Foulum, & $2013-$ & $\begin{array}{l}\text { Haldor Topsoe, } \\
\text { Ea, AU, }\end{array}$ & [124], [125] \\
\hline
\end{tabular}




\begin{tabular}{|c|c|c|c|c|c|}
\hline upgrading & & Denmark & 2016 & $\begin{array}{l}\text { PlanEnergi, } \\
\text { HMN Naturgas, } \\
\text { NGF, } \\
\text { EnergiMidt, } \\
\text { DGC, Cemtec, } \\
\text { Xergi }\end{array}$ & \\
\hline $\begin{array}{l}\text { Biogas } \\
\text { upgrading }\end{array}$ & $\begin{array}{l}\text { På Vej Mod } \\
\text { Metansamfundet } \\
\text { /Towards the methane } \\
\text { society }\end{array}$ & $\begin{array}{l}\text { Midtjylland, } \\
\text { Denmark }\end{array}$ & $\begin{array}{l}2011- \\
2012\end{array}$ & $\begin{array}{l}\text { Haldor Topsoe, } \\
\text { AU, AgroPark, } \\
\text { HIRC, } \\
\text { Planenergi, } \\
\text { GreenHydrogen, } \\
\text { HMN Naturgas, } \\
\text { Lemvig Biogas, } \\
\text { DTU, INBIOM }\end{array}$ & [130] \\
\hline $\begin{array}{l}\text { Biogas } \\
\text { upgrading }\end{array}$ & $\begin{array}{l}\text { MeGa-stoRE } 2 \text { - } \\
\text { Optimising and } \\
\text { Upscaling }\end{array}$ & $\mathrm{n} / \mathrm{a}$ & $\begin{array}{l}2015- \\
\mathrm{n} / \mathrm{a}\end{array}$ & $\begin{array}{l}\text { AU, NGF, } \\
\text { DTU, Elplatek, } \\
\text { GreenHydrogen }\end{array}$ & [141], [142] \\
\hline $\begin{array}{l}\text { Biogas } \\
\text { upgrading }\end{array}$ & $\begin{array}{l}\text { MeGa-stoRE - } \\
\text { Methane Gas storage } \\
\text { of Renewable Energy }\end{array}$ & $\begin{array}{l}\text { Lemvig, } \\
\text { Denmark }\end{array}$ & $\begin{array}{l}2013- \\
2015\end{array}$ & $\begin{array}{l}\text { AU, Elplatek, } \\
\text { GreenHydrogen, } \\
\text { Lemvig Biogas, } \\
\text { DTU-Mekanik, } \\
\text { AU Herning }\end{array}$ & [139] \\
\hline $\begin{array}{l}\text { Biogas } \\
\text { upgrading }\end{array}$ & SYMBIO & Denmark & $\begin{array}{l}2013- \\
2018\end{array}$ & $\begin{array}{l}\text { DTU- } \\
\text { Environment, } \\
\text { SDU, UM, } \\
\text { Energinet.dk, } \\
\text { Maabjerg } \\
\text { BioEnergy }\end{array}$ & [143], [145] \\
\hline $\begin{array}{l}\text { Biogas } \\
\text { upgrading }\end{array}$ & RENOVAGAS & Spain & $\begin{array}{l}2014- \\
2016\end{array}$ & $\begin{array}{l}\text { Enagas, ICP- } \\
\text { CSIC, CNH2, } \\
\text { FCC-Aqualia, } \\
\text { Gas Natural } \\
\text { Fenosa, } \\
\text { Tecnalia, } \\
\text { Abengoa }\end{array}$ & [146], [147] \\
\hline $\begin{array}{l}\mathrm{CO}_{2} \\
\text { methanation }\end{array}$ & $\begin{array}{l}\text { Technical } \\
\text { assumptions, } \\
\text { technology } \\
\text { demonstration and } \\
\text { results P2G project }\end{array}$ & $\begin{array}{l}\text { Rozenburg, } \\
\text { Netherlands }\end{array}$ & $\begin{array}{l}2013- \\
2015\end{array}$ & $\begin{array}{l}\text { DNV GL, TKI } \\
\text { Gas, Stedin, } \\
\text { Rotterdam } \\
\text { Council, Ressort } \\
\text { Wonen }\end{array}$ & [148], [151] \\
\hline $\begin{array}{l}\text { Syngas } \\
\text { upgrading }\end{array}$ & $\begin{array}{l}\text { Synthetic methane: a } \\
\text { medium for storage } \\
\text { and transportation of } \\
\text { excess renewable } \\
\text { energy }\end{array}$ & Netherlands & $\begin{array}{l}2011- \\
2014\end{array}$ & $\begin{array}{l}\text { ECN, TU-Delft, } \\
\text { Hanze UAS }\end{array}$ & $\begin{array}{l}\text { [153], [156], } \\
\text { [157] }\end{array}$ \\
\hline $\begin{array}{l}\text { Syngas } \\
\text { upgrading }\end{array}$ & DemoSNG & $\begin{array}{l}\text { Köping, } \\
\text { Sweden }\end{array}$ & $\begin{array}{l}2011- \\
2015\end{array}$ & $\begin{array}{l}\text { DVGW-EBI, } \\
\text { KIT, KTH, } \\
\text { Cortus, Gas } \\
\text { Natural Fenosa }\end{array}$ & [160], [163] \\
\hline $\begin{array}{l}\mathrm{CO}_{2} \\
\text { methanation }\end{array}$ & $\begin{array}{l}\text { Storage of electric } \\
\text { energy from } \\
\text { renewable sources in } \\
\text { the natural gas grid - }\end{array}$ & $\begin{array}{l}\text { Baden- } \\
\text { Wurtemberg, } \\
\text { Germany }\end{array}$ & $\begin{array}{l}2011- \\
2014\end{array}$ & $\begin{array}{l}\text { DVGW-EBI, } \\
\text { EnBW, } \\
\text { Fraunhofer ISE, } \\
\text { H-Tec, IoLiTec, }\end{array}$ & [165], [167] \\
\hline
\end{tabular}




\begin{tabular}{|c|c|c|c|c|c|}
\hline & $\begin{array}{l}\text { water electrolysis and } \\
\text { synthesis of gas } \\
\text { components }\end{array}$ & & & Outotec & \\
\hline $\begin{array}{l}\mathrm{CO}_{2} \\
\text { methanation }\end{array}$ & CO2-SNG & Poland & $\begin{array}{l}2014- \\
2017\end{array}$ & $\begin{array}{l}\text { Tauron, CEA, } \\
\text { Atmostat, AGH- } \\
\text { UST, IChPW, } \\
\text { Rafako, WT\&T } \\
\text { Polska }\end{array}$ & $\begin{array}{l}{[170],[173],} \\
{[174]}\end{array}$ \\
\hline $\begin{array}{l}\mathrm{CO}_{2} \\
\text { methanation }\end{array}$ & $\begin{array}{l}\mathrm{CO}_{2} \text { recycling via } \\
\text { reaction with } \\
\text { hydrogen }\end{array}$ & $\begin{array}{l}\text { Reno, } \\
\text { United States }\end{array}$ & 2009 & DRI, RCO2 AS & [175], [176] \\
\hline $\begin{array}{l}\mathrm{CO}_{2} \\
\text { methanation }\end{array}$ & $\begin{array}{l}\text { Pilot- und } \\
\text { Demonstrationsanlage } \\
\text { Power-to-Methane } \\
\text { HSR }\end{array}$ & $\begin{array}{l}\text { Rapperswil, } \\
\text { Switzerland }\end{array}$ & $\begin{array}{l}2014- \\
2015\end{array}$ & $\begin{array}{l}\text { HSR-IET, HSR, } \\
\text { Audi, } \\
\text { Climeworks, } \\
\text { Erdgas Obersee, } \\
\text { Erdgas Regio }\end{array}$ & [177], [178] \\
\hline $\begin{array}{l}\text { Biogas } \\
\text { upgrading }\end{array}$ & $\begin{array}{l}\text { Kommunale } \\
\text { Kläranlagen als } \\
\text { Energiespeicher }\end{array}$ & $\begin{array}{l}\text { Emden, } \\
\text { Germany }\end{array}$ & $\begin{array}{l}2012- \\
2014\end{array}$ & $\begin{array}{l}\text { Stadtwerke } \\
\text { Emden, BEE, } \\
\text { Thalen Consult, } \\
\text { ibis } \\
\text { Umwelttechnik, } \\
\text { GA-Group }\end{array}$ & $\begin{array}{l}\text { [184], [185], } \\
{[186]}\end{array}$ \\
\hline $\begin{array}{l}\mathrm{CO}_{2} \\
\text { methanation }\end{array}$ & $\begin{array}{l}\mathrm{CO}_{2} \text { Conversion to } \\
\text { Methane Project }\end{array}$ & $\begin{array}{l}\text { Rayong, } \\
\text { Thailand }\end{array}$ & $\begin{array}{l}2012- \\
2016\end{array}$ & $\begin{array}{l}\text { Hitachi Zosen, } \\
\text { DAE, PTTEP }\end{array}$ & [188], [190] \\
\hline $\begin{array}{l}\mathrm{CO}_{2} \\
\text { methanation }\end{array}$ & $\begin{array}{l}\text { Pilot plant - Tohoku } \\
\text { Institute of } \\
\text { Technology }\end{array}$ & $\begin{array}{l}\text { Tohoku, } \\
\text { Japan }\end{array}$ & $\begin{array}{l}2002- \\
2005\end{array}$ & $\begin{array}{l}\text { Tohoku } \\
\text { University, } \\
\text { TohTech, } \\
\text { Hokudai, DAE, } \\
\text { NRIM, MES, } \\
\text { Ryoka }\end{array}$ & [194], [195] \\
\hline $\begin{array}{l}\mathrm{CO}_{2} \\
\text { methanation }\end{array}$ & $\begin{array}{l}\text { Prototype plant - } \\
\text { Tohoku University }\end{array}$ & $\begin{array}{l}\text { Tohoku, } \\
\text { Japan }\end{array}$ & 1996 & $\begin{array}{l}\text { Tohoku } \\
\text { University, } \\
\text { IMR, TohTech, } \\
\text { Hokudai, DAE, } \\
\text { NRIM, MES, } \\
\text { Ryoka }\end{array}$ & [194], [195] \\
\hline $\begin{array}{l}\mathrm{CO}_{2} \\
\text { methanation }\end{array}$ & EE-Methan from CO2 & $\begin{array}{l}\text { Leoben, } \\
\text { Austria }\end{array}$ & $\begin{array}{l}2013- \\
2016\end{array}$ & $\begin{array}{l}\text { JKU Linz, MU } \\
\text { Leoben, TU } \\
\text { Wien, Christof } \\
\text { Group, } \\
\text { Profactor, } \\
\text { ÖVGW, FGW }\end{array}$ & $\begin{array}{l}\text { [198], [203], } \\
{[204]}\end{array}$ \\
\hline $\begin{array}{l}\text { Biogas } \\
\text { upgrading }\end{array}$ & OptFuel & $\begin{array}{l}\text { Leoben, } \\
\text { Austria }\end{array}$ & $\begin{array}{l}2013- \\
2016\end{array}$ & $\begin{array}{l}\text { JKU Linz, MU } \\
\text { Leoben, TU } \\
\text { Wien, Christof } \\
\text { Group, } \\
\text { Profactor, } \\
\text { ÖVGW, FGW }\end{array}$ & $\begin{array}{l}\text { [199], [204], } \\
{[207]}\end{array}$ \\
\hline $\begin{array}{l}\mathrm{CO}_{2} \\
\text { methanation }\end{array}$ & $\begin{array}{l}\text { P2G Solar Energy } \\
\text { Storage RD\&D }\end{array}$ & $\begin{array}{l}\text { Golden, } \\
\text { United States }\end{array}$ & $\begin{array}{l}2014- \\
2016\end{array}$ & $\begin{array}{l}\text { NREL, } \\
\text { SoCalGas }\end{array}$ & [209], [210] \\
\hline
\end{tabular}




\begin{tabular}{|c|c|c|c|c|c|}
\hline \begin{tabular}{l|}
$\mathrm{CO}_{2}$ \\
methanation \\
/ Biogas \\
upgrading
\end{tabular} & RENERG $^{2}$ & $\begin{array}{l}\text { Villigen, } \\
\text { Switzerland }\end{array}$ & $\begin{array}{l}2013- \\
2016\end{array}$ & $\begin{array}{l}\text { PSI, EMPA, } \\
\text { ETH Zurich, } \\
\text { ZHAW, EPFL }\end{array}$ & [212], [214] \\
\hline $\begin{array}{l}\mathrm{CO}_{2} \\
\text { methanation }\end{array}$ & $\begin{array}{l}\text { Catalytic methanation } \\
\text { of industrially- } \\
\text { derived } \mathrm{CO}_{2}\end{array}$ & $\begin{array}{l}\text { Dübendorf, } \\
\text { Switzerland }\end{array}$ & $\begin{array}{l}2014- \\
2017\end{array}$ & EMPA, ZHAW & [218], [220] \\
\hline $\begin{array}{l}\text { Biogas } \\
\text { upgrading }\end{array}$ & SmartCat & $\begin{array}{l}\text { Dübendorf, } \\
\text { Switzerland }\end{array}$ & $\mathrm{n} / \mathrm{a}$ & $\begin{array}{l}\text { EMPA, ZHAW, } \\
\text { Zeochem, VSG }\end{array}$ & [217], [219] \\
\hline $\begin{array}{l}\mathrm{CO}_{2} \\
\text { methanation }\end{array}$ & HyTech & $\begin{array}{l}\text { Dübendorf, } \\
\text { Switzerland }\end{array}$ & $\begin{array}{l}2012- \\
2015\end{array}$ & $\begin{array}{l}\text { EMPA, ZHAW, } \\
\text { EPFL, PSI }\end{array}$ & [212] \\
\hline \begin{tabular}{l|l}
$\mathrm{CO}_{2}$ \\
methanation
\end{tabular} & $\begin{array}{l}\mathrm{CO}_{2} \text {-Methanation of } \\
\text { flue gas }\end{array}$ & $\begin{array}{l}\text { Brandenburg, } \\
\text { Germany }\end{array}$ & $\begin{array}{l}2013- \\
2015\end{array}$ & $\begin{array}{l}\text { BTU, Panta } \\
\text { Rhei, Vattenfall }\end{array}$ & $\begin{array}{l}\text { [222], [223], } \\
{[225]}\end{array}$ \\
\hline $\begin{array}{l}\mathrm{CO}_{2} \\
\text { methanation }\end{array}$ & $\begin{array}{l}\mathrm{CO}_{2} \text { catalysis, pilot } \\
\text { plant - Technikum } 1 \\
\& 2\end{array}$ & $\begin{array}{l}\text { Cottbus, } \\
\text { Germany }\end{array}$ & $\begin{array}{l}2013- \\
2014\end{array}$ & BTU & [225], [230] \\
\hline \begin{tabular}{l|l}
$\mathrm{CO}_{2}$ \\
methanation
\end{tabular} & GeoEn & $\begin{array}{l}\text { Cottbus, } \\
\text { Germany }\end{array}$ & $\begin{array}{l}2011- \\
2013\end{array}$ & $\begin{array}{l}\text { BTU, GFZ, } \\
\text { Uni-Postdam }\end{array}$ & $\begin{array}{l}\text { [227], [228], } \\
\text { [229] }\end{array}$ \\
\hline $\begin{array}{l}\mathrm{CO}_{2} \\
\text { methanation }\end{array}$ & $\begin{array}{l}\text { Dual function } \\
\text { materials for } \mathrm{CO}_{2} \\
\text { capture and } \\
\text { conversion using } \\
\text { renewable } \mathrm{H}_{2}\end{array}$ & $\begin{array}{l}\text { New York, } \\
\text { United States }\end{array}$ & $\begin{array}{l}2013- \\
2015\end{array}$ & $\begin{array}{l}\text { Columbia } \\
\text { University, } \\
\text { BASF }\end{array}$ & $\begin{array}{l}\text { [232], [233], } \\
{[234]}\end{array}$ \\
\hline $\begin{array}{l}\mathrm{CO}_{2} \\
\text { methanation }\end{array}$ & $\begin{array}{l}\text { Biocatalytic } \\
\text { methanation in an } \\
\text { anaerobic three-phase } \\
\text { system }\end{array}$ & $\begin{array}{l}\text { Cottbus, } \\
\text { Germany }\end{array}$ & $\begin{array}{l}2013- \\
2015\end{array}$ & BTU-FESPE & [235], [236] \\
\hline
\end{tabular}

*Note: Photo-electrochemical water splitting

There also exist other facilities and projects that apply methanation without making use of renewable hydrogen. However, they are beyond the scope of this review and are not included in the following subsections.

\subsection{ETOGAS - Audi e-gas plant}

The Audi e-gas plant, under operation since 2013 and located in Werlte (Germany), is the largest industrial Power to SNG facility built in the world (6 $\left.\mathrm{MW}_{\mathrm{e}}\right)$. It is based in the catalytic methanation of pure hydrogen and carbon dioxide in a single isothermal fixed-bed reactor [73][74]. 
The hydrogen comes from 3x2.0 $\mathrm{MW}_{\mathrm{e}}$ alkaline electrolysers powered by an offshore wind park in the North Sea, which comprises 4x3.6 $\mathrm{MW}_{\mathrm{e}}$ turbines and it is co-financed by Audi AG and a regional power-supply company [75]. In addition, the required $\mathrm{CO}_{2}$ is separated from the raw biogas of a neighbouring biomethane plant, belonging to EWE Biogas GmbH \& Co. KG, by means of amine scrubbing [76].

The Power to Gas process of Audi has $54 \%$ efficiency (without accounting the utilization of the by-produced thermal energy), thus obtaining a SNG with 13.85 $\mathrm{kWh} / \mathrm{kg}$ of energy content. The maximum output flow of the facility is $325 \mathrm{Nm}^{3} / \mathrm{h}$, but it is only expected a production of roughly 1000 tons per year, because of the availability of the renewable energy consumed to produce the hydrogen (4000 hours per annum) [77].

The Power to Gas plant, in contrast to the biogas plant, is not operated on a stationary basis but following the energy supply pattern. Furthermore, the plant has been recently qualified for participating in the electricity balancing market, after successfully draw 6 $\mathrm{MW}_{\mathrm{e}}$ of power from the grid within five minutes as well as run prescribed load profiles [78]. The thermal management of the waste heat recovered from electrolysis and methanation, to supply the various heat consumers in the biogas and $\mathrm{CO}_{2}$ removal plants (mainly amine regeneration), is highly complex [79]. Hence, the assessment and optimization of the plant operation is provided by the WOMBAT simulation [80].

The construction of the plant was born from a collaborative project between Audi AG, ETOGAS GmbH (formerly named Solar Fuel GmbH), the Centre for Solar Power and Hydrogen Research Baden-Württemberg (ZSW), the Fraunhofer Institute for Wind Energy and Energy System Technology (Fraunhofer IWES) and EWE Biogas GmbH \& Co. KG [81]. 
The entire research plan dates back to 2009, in Stuttgart, with ETOGAS as manufacturer and ZSW as the chief developer. The several stages that have been required for achieving the current demonstration plant were performed in Germany in the following order [82]:

- Power to Gas $\alpha$-plant with air purification (Stuttgart, 2009): A $25 \mathrm{~kW}_{\mathrm{e}}$ electrolyser coupled to a $\mathrm{CO}_{2}$ ambient air purification system was the initial installation used for demonstrating the basic feasibility of the Power to Gas process. The partner and co-developer of this early research stage was ZSW. The facility was built as a mobile container laboratory with a $\mathrm{CH}_{4}$-filling station of $15 \mathrm{~kg}$ capacity at 200 bar. The total efficiency achieved without optimizations was $40 \%$ [83][84].

- Power to Gas $\alpha$-plant with $\mathrm{CO}_{2}$ from biogas purification (Werlte, 2010 - 2011): The second phase implied the implementation of the methanation with carbon dioxide captured by pressure swing adsorption (PSA) from the EWE Biogas plant. Hence, the $\alpha$-plant was tested at the current location of the Audi e-gas project, and it was formed a three member alliance [85].

- Power to Gas $\alpha$-plant with raw biogas (Morbach, 2011): For the first time, the $\alpha$ plant was operated with raw biogas instead of pure $\mathrm{CO}_{2}$. It was demonstrated that direct methanation of biogas is technically feasible in a PtG plant. In this stage, Juwi AG joined to the previous partners [85][86].

- Power to Gas $\alpha$-plant in long period operation with raw biogas (Bad Hersfeld, 2012): This research stage corresponds to a project launched at the Fraunhofer IWES, in collaboration with ZSW. The target was in situ methanation with raw biogas from an agricultural biogas plant located in the Hessian Biogas Research 
Centre (HBFZ). The $\alpha$-plant property of ETOGAS was integrated in the already existent infrastructure for long period operation despite the fluctuating raw biogas composition [87].

- Power to Gas $250 \mathrm{~kW}_{\mathrm{e}}$ test facility (Stuttgart, 2012-2014): ZSW, Fraunhofer IWES and ETOGAS developed the largest PtG plant of this type at that time [88]. The main objective was to examine and test different fixed-bed reactor technologies for methanation (plate versus tubular reactor construction) [74]. The system is composed by two fixed-bed reactors, with a capacity for 50 litres of catalyst. The first one is refrigerated by water, whilst the other by molten salt. Also, there exists a condensation stage between both methanators, and a recirculation of the final gas towards the first reactor [84]. The methane content achieved is $99 \%$, thanks to processing the gas with membrane technology after methanation. Furthermore, the $250 \mathrm{~kW}$ alkaline pressure electrolyser was operated in dynamic and intermittent mode, enabling flexible respond to fluctuating solar and wind energy supplies [82].

Its main goal was to reach commercialized PtG systems around 20 MW between 2015 and 2017, with efficiency above $80 \%$ thanks to the recovery of the extra thermal heat from methanation [89].

\subsection{Electrochaea - BioCat}

The Power-to-Gas via Biological Catalysis (P2G-BioCat) project, which was launched in February 2014 [90], aims to develop the world's largest commercial-scale plant for converting biogas into methane through biological methanation [91]. The facility, located in Avedøre (Denmark), will be operated in dynamic mode to demonstrate its ability to provide energy storage services to the Danish energy system [92]. 
The construction phase began in July 2015 at the Avedøre Wastewater Treatment Plant, and the facility is expected to be operational by April 2016 [93]. The carbon dioxide source may be raw biogas from an anaerobic digester $\left(60 \% \mathrm{CH}_{4}\right.$ and $\left.40 \% \mathrm{CO}_{2}\right)$ or pure $\mathrm{CO}_{2}$ supplied by a conventional biogas upgrading system [94]. The hydrogen will come from a $1 \mathrm{MW}_{\mathrm{e}}$ alkaline electrolyser provided by Hydrogenics, which is scheduled to be shipped in early December 2015 [95]. It will be fed with local excess wind power, and the by-product oxygen will be recycled into the wastewater treatment process. Additionally, the heat from methanation will be also integrated, and the final synthetic natural gas produced is destined to be injected into the 4 bar distribution grid [96].

The methanation will be performed in a liquid phase reactor by methanogenic archaea, a single-celled microorganism which has been selectively evolved through survival tests by Electrochaea GmbH. It metabolizes the hydrogen and carbon dioxide to methane in sequential reduction steps in which the $98.6 \%$ of carbon is fixed into the product. The archaea works at low temperatures $\left(60-65{ }^{\circ} \mathrm{C}\right)$ and present high tolerance for hydrogen sulfide, nitrogen oxides, ammonia, particles, as well as partial tolerance for oxygen and ethanol [96].

The project has an overall budget of $€ 6.7$ million partially supported by the ForskELprogramme (€3.7 million), which is managed by Energinet.dk, the operator of the Danish power and gas transmission grids. The beneficiary consortium is led by the developer of the methanation technology, Electrochaea, and includes the partners Hydrogenics, Audi, NEAS Energy, HMN Gashandel A/S, Biofos A/S, and Insero Business Services [91][92].

The previous research necessary to achieve the current state of development in this project has passed through three relevant phases. Furthermore, Electrochaea participates 
in two new H2020 projects that has been recently launched following BioCat [97][98] . The three previous research stages and the newly started H2020 projects are summarized in the following:

- Basic research and proof of concept (2006 - 2010): The scientific basis of the technology was established in The University of Chicago by Dr. Laurens Mets, the inventor of Electrochaea's biocatalyst [86][96].

- Lab-scale $1 \mathrm{~kW}$ (2011): Electrochaea successfully tested the bio-catalytic capability of archaea using raw biogas coming from the digester of a brewery waste plant located in St. Louis. It contained $30 \% \mathrm{CO}_{2}, 68 \% \mathrm{CH}_{4}$ and up to 7000 ppm of hydrogen sulfide [99][100].

- Pre-commercial $250 \mathrm{~kW}$ (2013): Electrochaea demonstrated the technology in a pre-commercial setting using a 10000 liter non-optimized reactor, a $250 \mathrm{~kW}$ PEM electrolyser, and raw biogas [100][101]. The project was operated over 3000 hours under realistic market conditions at Aarhus University’s Biogas Research Center in Foulum. It was partially funded with a grant of $€ 0.88$ million from the Danish Energy Agency [102], and the partners of the project were E.ON AG, Energie 360 AG, Elektrizitätswerk der Stadt Zürich (EWZ), and NEAS Energy [103] .

- POWERSTEP (2015 - 2018): This project, launched in September 2015, aims to convert wastewater treatment plants in new renewable power producers. The concept will be demonstrated in 6 full-scale studies among Austria, Denmark, Germany, Sweden and Switzerland. Different technologies will be implemented, including Power to Gas developed by Electrochaea. The budget amounts to €5.2 
million, and is funded with $€ 4.0$ million through the H2020 programme [104][105] .

- STORE \& GO (2015 - 2019): Up to 19 industrial and academic partners will demonstrate Power to Gas technology in Switzerland, Germany and Italy, for preventing further construction of new power lines. The project began in September 2015 and puts together multiple institutions researching on methanation like the Swiss Federal Institute of Technology in Lausanne (EPFL), the Swiss Federal Laboratories for Materials Science and Technology (EMPA) and Deutscher Verein des Gas- und Wasserfaches e.V. (DVGW) [98][106].

\subsection{MicrobEnergy - BioPower2Gas}

BioPower2Gas is the first Power to Gas plant based in biological methanation that has achieved the commercial status in the world. This has been constructed in a 3 year project located in Allendorf (Germany) that was launched in September 2013. The first injection of SNG into the national gas grid took place in March 2015, and the finishing certification of the plant was obtained in April 2015 [107].

The equipment of the facility has been provided by subsidiaries of the Viessmann Group. The PtG plant is composed by $2 \times 150 \mathrm{~kW}_{\mathrm{e}}$ PEM electrolysers and a $\mathrm{H}_{2}$ buffer from Carbotech, a $5 \mathrm{~m}^{3}$ biological reactor from MicrobEnergy $\mathrm{GmbH}$, and system controls from Schmack Biogas GmbH [107]. Moreover, the biogas can come from the two biogas plants (dry or wet fermentation) that Viessmann owns in the area [108].

The first injection of SNG, into the gas grid, consumed $15 \mathrm{Nm}^{3} / \mathrm{h}$ of hydrogen for the methanation process. However, the potential production of the electrolyser is $60 \mathrm{Nm}^{3} / \mathrm{h}$. Furthermore, Viessmann aims to extend the research up to $1,2 \mathrm{MW}_{\mathrm{e}}$ aiming to reduce 
the specific cost of the entire facility from $10000 € / \mathrm{kW}$ to $1200 € / \mathrm{kW}$ for the year 2017 [109]. In addition to the Viessmann companies, the beneficiary partners are EnergieNetz Mitte GmbH (network operator), EAM EnergiePlus GmbH (utilities company), CUBE (engineering consultants) and the project coordinator Institute decentralised Energy Technologies (IdE). Moreover, the German Biomass Research Center (DBFZ) has provided scientific support [110].

Prior the BioPower2Gas project, MicrobEnergy led the line of research of Viessmann, which could be resumed in four development stages:

- Lab-scale research: The proof of the concept was performed at laboratory with a 10 litres reactor, increasing the methane content of biogas from $60 \%$ to $95 \%$ [111].

- Biological methanation of pure streams: A biological reactor for the methanation of pure carbon dioxide and hydrogen was installed in Schwandorf (Germany), coupled to a $55 \mathrm{~kW}$ electrolyser. The reactor worked at ambient pressure and had an external heat supply to achieve the necessary operation temperatures (40 $-65^{\circ} \mathrm{C}$ ). The results showed that the reactor was able to handle a flow 30 times its size [73].

- Methanation of raw biogas (2011): The objective of the project was to upgrade biogas, during its formation inside the digester, through biological methanation. The biogas reactor was supplied with maize and grass, whilst the hydrogen came from a $120 \mathrm{~kW}_{\mathrm{e}}$ electrolyser that produced $21.3 \mathrm{Nm}^{3} / \mathrm{h}$. The methanogenic bacteria consumed the hydrogen, which was introduced from the bottom, as it rose in the reactor through the viscous liquid. Thus, the methane content 
increased from 50 to $75 \%$ and it was obtained a SNG flow of $5.3 \mathrm{Nm}^{3} / \mathrm{h}$ [73][112].

- Methanation of biogas from wastewater (2013): MicrobEnergy installed a 180 $\mathrm{kW}_{\mathrm{e}}$ PEM electrolyser at the wastewater plant of Schwandorf (ZVKSW), in collaboration with the Research Center for Power Grids and Energy Storage (FENES) from Universität Regensburg [113]. The goal was to study the stability and reaction rate of the biological methanation under real conditions, by introducing the hydrogen (approximately $30 \mathrm{Nm}^{3} / \mathrm{h}$ ) directly in the digester as in the previous research [114]. The project budget of $€ 1,42$ million was partially funded with a €0.53 million grant [115].

\subsection{Sunfire - HELMETH}

Sunfire GmbH is involved in the HELMETH project (Integrated High-Temperature Electrolysis and Methanation for Effective Power to Gas Conversion), launched in April 2014 with a time horizon of three years. It aims to demonstrate efficiencies above $85 \%$ in Power to Gas systems by integrating high temperature electrolysis and $\mathrm{CO}_{2}$ methanation [116]. Thus, Sunfire continues the research on SOEC technology developed in a prior Power to Liquid project [117][118].

Electrolysis research will be conducted in a $15 \mathrm{~kW}$ SOEC [119] working at $800{ }^{\circ} \mathrm{C}$ and 15 bar, whilst methanation process will comprise two reactors in series at $300{ }^{\circ} \mathrm{C}$ and 30 bar, with intermediate water removal [120] thus producing up to $5.4 \mathrm{~m}^{3} / \mathrm{h}(60 \mathrm{~kW})$. The plant is expected to be constructed by mid-2016 [121], managing partial loads down to $20 \%$ [120]. Moreover, first results concerning catalyst show higher conversions and stability by adding composite oxides to the $\gamma-\mathrm{Al}_{2} \mathrm{O}_{3}$ substrate [122]. 
The project consortium is leaded by the Karlsruhe Institute of Technology (KIT), and formed by Sunfire, Politecnico di Torino (PoliTo), European Research Institute of Catalysis AISBL (ERIC), Turbo Service Torino spa, National Technical University of Athens (NTUA), and DVGW [116]. The budget totals €3.8 million, funded with €2.5 million from the European Union’s Seventh Framework Programme [123].

\subsection{Haldor Topsoe - El-Opgraderet Biogas}

The El-Opgraderet Biogas project aims to construct and operate a pilot plant in Foulum (Denmark) that upgrades biogas by consuming hydrogen from a $40 \mathrm{~kW}_{\mathrm{e}}$ SOEC electrolyser. The project was launched in June 2013 for three years [124], but no information has been released so far.

The $€ 5.3$ million budget was funded with €3.5 million through the EUDP Danish program. Moreover, although Haldor Topsoe A/S leads the project, the Aarhus University (AU) received the $70 \%$ of the grant for constructing the demonstration plant [125]. The rest of the partners are HMN Naturgas I/S, Naturgas Fyn I/S, EnergiMidt, Xergi A/S, Danish Gas Technology Centre (DGC), PlanEnergi.dk, Ea Energianalyse A/S, and Cemtec [126].

During the past years, Haldor Topsoe has intensively researched in SOEC electrolysis for PtG, although in a theoretical perspective in most cases. Moreover, another project was launched in July 2015 for the period 2015 - 2019. Their timeline of research can be summarized as follows:

- GreenSynFuels (2010 - 2011): This project analysed technologies for the development of methanol and DME as green synthetic fuels, through technoeconomical calculations. The most favored concept was the methanol synthesis 
based on gasification of wood assisted by hydrogen from a SOEC electrolyser [127]. The budget amounted to $190 \mathrm{k} €$ and was partially funded by the EUDP Danish program [128].

- Biogas SOEC (2011 - 2012): The project studied two upgrading routes based in SOEC electrolysers: the direct methanation of biogas by adding hydrogen, and the co-electrolysis of biogas with steam to produce $\mathrm{CO}$ and $\mathrm{H}_{2}$ for a subsequent methanation. Furthermore, the presence of sulphur in the biogas supplied to the SOEC was investigated experimentally [129]. The budget of the project was $180 \mathrm{k} €$ (67 \% funded by the ForskNG program) [128].

- Towards the Methane Society (2011 - 2012): Haldor Topsoe constructed a three-reactor pilot plant for purifying biogas, which was operated for 1000 hours at the Aarhus University. The two first reactors reduced the sulfur content below $0.04 \mathrm{ppmv}$, and the third removed the remaining traces. Moreover, the hydrogen was supplied prior the entrance of the last cleaning reactor to consume the oxygen contained in the biogas, thus preparing it for the Sabatier reaction. However, no methanation experiments were performed. Furthermore, the El-opgraderet biogas project, which is currently in progress, arose from this research as a second development phase [130]. The budget amounted to $214 \mathrm{k} €$ [131].

- $\mathrm{CO}_{2}$ Electrofuels (2011 - 2013): This project quantified the cost potential of several fuel synthesis (methane, methanol and DME), and elaborated a roadmap for the their introduction in the Nordic region [132]. The research was funded by the Nordic Energy Research Programme [133]. 
- Green Natural Gas (2011 - 2014): The Green Natural Gas project identified $\mathrm{CO}_{2}$ and heat sources for methanation based on SOEC, and provided a technology roadmap through cost-analysis [134][135]. Moreover, dynamic properties for SOEC were tested at Haldor Topsoe facilities. The budget amounted to $€ 3.2$ million and was funded with $€ 1.7$ million through the EUDP program [136].

Besides biogas upgrading, Haldor Toposoe has launched a new project named SYNFUEL (2015 - 2019) to explore a PtG process in which carbon source comes from syngas. This project aims to be a proof-of-principle of the combination of SOEC electrolysis and oxygen-blow gasification of biomass. Innovation Fund Denmark granted the project with €2.8 million, whose budget amounts to €3.8 million [137].

\subsection{Aarhus University - MeGa-stoRE}

The MeGa-stoRE (Methane Gas Storage of Renewable Energy) project has developed a proof-of-concept plant for upgrading biogas through catalytic methanation. Aarhus University launched the project in 2013 for two years, inspired by its participation in the Towards to the Methane Society project [138]. It was initially located in its Department of Business Development and Technology (AU Herning) for designing and construction, later continued at GreenHydrogen.dk for testing, and finally the equipment was mounted in a container and transported to Lemvig Biogas Amba for operation [139].

The plant comprises a cleaning unit and a methanation reactor. Firstly, a two-step catalytic process purifies biogas and converts contaminants into micronutrients for the 
digested slurry. Thus, the $\mathrm{H}_{2} \mathrm{~S}$ content is maintained below $30 \mathrm{ppb}$. After cleaning, biogas is methanised using bottled hydrogen, in a single air-cooled reactor [139].

The technology was verified in four long-term tests ranging from 15 to 24 hours. All the experiments showed stability and final methane contents between 97 - $99 \%$. The reactor temperature was set to $270{ }^{\circ} \mathrm{C}$, the pressure was kept at 8 bars and the biogas flow rate was $720 \mathrm{~L} / \mathrm{h}[139]$.

Besides Aarhus University, which was the project manager, five more partners conformed the consortium: GreenHydrogen, Elplatek A/S, Lemvig Biogas, Department of Mechanical Engineering of the Technical University of Denmark (DTU-Mekanik), and AU Herning [139]. The ForskEL program partially funded the budget of $900 \mathrm{k} €$ with a 300 k€ grant [140]. Furthermore, DTU-Mekanik has continued the research by launching a pre-commercialisation project called MeGa-stoRE Optimising and Upscaling, for 2015 onward. The budget amounts to €3.5 million, and ForskEL grants the $25 \%$ [141]. The new objective is to achieve SNG productions of $10 \mathrm{Nm}^{3} / \mathrm{h}$ [142].

\subsection{Technical University of Denmark - SYMBIO}

Besides the collaborative projects with Aarhus University and Haldor Topsoe, the Technical University of Denmark (DTU) leads the SYMBIO project. This research aims to develop the biogas upgrading through the injection of renewable hydrogen into the anaerobic digester. The project was launched in 2013 with a time horizon of five years [143], although DTU had developed previous research experiences in this topic [144].

The two main objectives of the project are to establish a technical solution for the hydrogen injection, and to evaluate the increment in the biogas produced by a secondary injection of $\mathrm{CO}_{2}$. However, no results have been released so far [145]. 
The project consortium is composed by the Department of Environmental Engineering of the Technical University of Denmark (DTU-Environment), University of Southern Denmark (SDU), Energinet.dk, Maabjerg BioEnergy A/S, and the Department of Microbiology and Immunology from the University of Montreal (UM-DMI). The budget amounts to €2.3 million funded with €1.7 million [143].

\subsection{Enagas - RENOVAGAS}

RENOVAGAS aims to develop the first Spanish pilot plant for upgrading biogas through methanation. The project was launched in July 2014, and is planned its conclusion by December 2016. Moreover, as final goal, the SNG produced should have enough quality for its injection to the gas grid [146].

The plant will be constructed along 2015 and operated in 2016. A containerized design will be used for delivering the facility to a biogas plant belonging to FCC-Aqualia S.A., which is expected to produce up to $2 \mathrm{Nm}^{3} / \mathrm{h}$ of SNG. The pilot will comprise a $15 \mathrm{~kW}$ alkaline electrolyser, a modular multichannel reactor with oil-based cooling, and the control systems. The methanator will operate at 25 bar and $275-330{ }^{\circ} \mathrm{C}$ with a gas space velocity between $2000-20000 \mathrm{~h}^{-1}$, and the catalysts will be made of $\mathrm{Ni}$ or $\mathrm{Ru}$, supported on $\mathrm{Al}_{2} \mathrm{O}_{3}$ [146].

Enagas S.A., which is the technical manager of the Spanish gas system, leads this project with a consortium composed by the Institute of Catalysis and Petrochemistry (ICP-CSIC), the National Centre for Hydrogen and Fuel Cell Technology (CNH2), FCC-Aqualia, Gas Natural Fenosa, Tecnalia, and Abengoa Hidrógeno. The budget amounts to $€ 1.7$ million, and is funded with $€ 1.2$ million by the Spanish Ministry of Economy and Competitiveness (MINECO) [146]. 
Based on the results of this project, it is planned to scale up the system by constructing a $250 \mathrm{~kW}$ pilot plant in a second project. Finally, a last stage would build a 5 MW commercial infrastructure [147].

\subsection{DNV GL - Power to Gas in Rozenburg}

The DNV GL Group has developed the first Power to Gas facility in Netherlands. The project objective was to validate the capability of the PtG technology to regulate power production, by injecting SNG into the gas network. The plant, located in Rozenburg, provides natural gas to 30 nearby apartments [148] since its inauguration in October 2014 [149]. The lab-scale research began in 2011 [150], the project was initiated in 2013 and the final report has been released in 2015 [151].

The facility comprises a $7 \mathrm{~kW}$ commercial PEM electrolyser (model Hogen S40), a four-reactor methanation system, and two $\mathrm{CO}_{2}$ tanks, placed in three individual containers. Four solar panels, on the containers' roofs, partially supply the hydrogen production, whilst the electricity grid provides the remaining demand. Moreover, the carbon dioxide comes from a wholesale distributor [151].

The methanators are made of stainless steel $316 \mathrm{~L}$ with a capacity of $1.06 \mathrm{~L}$ for each, filled with different commercial catalysts depending on $\mathrm{H}_{2}$ and $\mathrm{CO}_{2}$ concentrations. The two first reactors use $11 \% \mathrm{w}$ Ni catalysts to avoid exceeding the temperature requirements, whilst the third and fourth reactors use $37 \% \mathrm{w}$ and $54 \% \mathrm{w}$ Ni contents, respectively. Hence, reactors can work at temperatures between $150-700{ }^{\circ} \mathrm{C}$ and pressures below 15 bar, although the best results are obtained at $377^{\circ} \mathrm{C}$ and less than 8 bar. Lastly, the entire plant can be started up in approximately 40 minutes while the electrolyzer is completely operative after just 4 minutes [151][152]. 
The project emerged from the cooperation between DNV GL, the Rotterdam Council, and Ressort Wonen, with funding from Stedin (grid operator) and TKI Gas.

\subsection{ECN - Synthetic Methane}

The Synthetic Methane project analysed the upgrading of syngas, by simulation, under scenarios of energy excess -addition of renewable hydrogen- and energy demand conventional operation by removing $\mathrm{CO}_{2}$ excess-- Moreover, a novel sorption enhanced methanation was proposed and tested experimentally [153]. The project was launched in November 2011 [154], and later extended to December 2014 through a complementary work-package regarding SOFC [155].

For the thermodynamic simulation, three methanation configurations were considered: 3-reactor and 2-reactor schemes with recirculation over the first methanator, and 3reactor scheme with recirculation from the second to the first methanator. Results showed that 3-reactor schemes are preferred. Furthermore, recycling over the first methanator reduces the size required for the following reactors and improves the operational control, although the heat available for external integration diminishes. Additionally, it was found that adding renewable $\mathrm{H}_{2}$ to the syngas upgrading impacts on the economics rather than on methanation efficiency [156].

The experimental tests were performed at the methanation facility of the Energy Research Centre of the Netherlands (ECN), developed during the prior project Advance Green Gas Technology Development, which was focused on the conventional syngas upgrading (i.e., without renewable $\mathrm{H}_{2}$ addition). This equipment works at 6 bar with a gas space velocity of $2000 \mathrm{~h}^{-1}$, and comprises one pre-reformer at $340{ }^{\circ} \mathrm{C}$ for the 
conversion of aromatic hydrocarbons, followed by two methanation reactors at $230{ }^{\circ} \mathrm{C}$ and $240{ }^{\circ} \mathrm{C}$, respectively [157].

In the proposed sorption enhanced methanation, zeolite $4 \mathrm{~A}$ is added to the catalyst to simultaneously dehydrate the SNG inside the reactor. Later, water is desorbed through a regenerative process using heat from methanation. Large methane yields were found even at pressures below 10 bar, thus reducing compression consumptions and increasing efficiency [158].

The project was carried out by ECN, Delft University of Technology (TU-Delft), and Hanze University of Applied Sciences (Hanze UAS). The budget amounted to €1.3 million, and it was financed through the EDGaR programme [154].

\subsection{DVGW-EBI and KIT - Demo-SNG}

The DemoSNG project demonstrated the feasibility of syngas upgrading by developing a new reactor concept based in honeycomb nickel catalyst [159]. The project was launched in 2011 and concluded during 2015 [160].

The pilot plant was installed into a standard container for shipping purposes. Gas Natural Fenosa was in charge of the hydrogen production [161] through PEM electrolysis [162], and KTH Royal Institute of Technology (KTH) of the hot syngas cleaning process (sulphur, nitrogen and ash removal) [160]. Karlsruhe Institute of Technology (KIT) performed the initial tests, and Cortus operated the pilot at their biomass gasification plant in Köping, Sweden [159].

The proposed methanation uses a single reactor that prevents catalyst degradation through an improved temperature control. The heat transfer from the catalyst to the cooling fluid was simplified by immobilising the catalyst on a metallic monolithic 
structure (honeycomb). Thus, the process runs below $300{ }^{\circ} \mathrm{C}$ [163], and the facility can process up to $14 \mathrm{Nm}^{3} / \mathrm{h}$ of raw biogas [160].

KIT coordinated the project. Moreover, DVGW-Forschungsstelle at the Engler-Bunte Institute (DVGW-EBI) participated in the research. KTH, Cortus, and Gas Natural Fenosa completed the consortium. The project was supported by KIC InnoEnergy with $€ 4.5$ million [159][161].

Furthermore, DVGW-EBI led a related project between 2011 and 2014 [164], called SEE project (Storage of electric energy from renewable sources in the natural gas gridwater electrolysis and synthesis of gas components). Their research focused on comparing fixed-bed and slurry methanators at lab-scale, besides studying dynamic operation of electrolysers [165].

The Fraunhofer Institute for Solar Energy Systems (Fraunhofer ISE) characterized a 6 kW PEM electrolyser, provided by H-Tec Systems, by simulating realistic load profiles [166]. Outotec studied different catalysts in a single fixed-bed reactor by varying the inlet and reaction temperatures as well as the gas space velocity. The methanator was 73 $\mathrm{cm}$ high and $10 \mathrm{~cm}$ in diameter, with a $10 \mathrm{~cm}$ catalyst layer in the middle. It was fed by selecting the gas composition through different pure gas bottles, achieving up to $70 \%$ $\mathrm{CO}_{2}$ conversions [167]. DVGW-EBI developed slurry reactors filled with liquid property of Ionic Liquids Technologies GmbH (IoLiTec) in which catalyst is finely distributed. This fluid efficiently dissipates the reaction heat, thus enabling an accurate temperature control under fluctuating feed streams. Catalyst particles are suspended by the rising gas bubbles and can be replaced during operation. Finally, Energie BadenWürttemberg AG (EnBW) evaluated the economic viability. 
Although the SEE project is already concluded, DVGW-EBI is still improving the slurry methanation process by testing two reactors with diameters of $24.6 \mathrm{~mm}$ and 54.5 mm, and height/diameter ratios of 26 and 13, respectively [168]. Furthermore, DVGWEBI and the KIT are also studying together the combination of the slurry reactor in series with the honeycomb methanation [169].

\subsection{Tauron $-\mathrm{CO}_{2}-\mathrm{SNG}$}

The $\mathrm{CO}_{2}$-SNG project $\left(\mathrm{CO}_{2}\right.$ methanation system for electricity storage through SNG production) aims to develop a pilot plant for consuming $\mathrm{CO}_{2}$ from industry facilities [170]. Tauron Group, as leader, launched the project in 2014 [171] and planned the commissioning of the plant for the first quarter of 2017 [172].

The Power to Gas facility will be located in a coal-burning power plant of Tauron, in Poland [172]. The French partners, the Atomic Energy and Alternative Energies Commission (CEA) and Atmostat, have already developed a structured reactor that processes $1 \mathrm{Nm}^{3} / \mathrm{h}$ with a $95 \%$ conversion rate. The final design will treat up to 25 $\mathrm{Nm}^{3} / \mathrm{h}$ and is expected to be delivered in mid-2016 [173]. The AGH University of Science and Technology (AGH-UST) select and test the catalyst for the methanation reaction. The Institute for Chemical Processing of Coal (IChPW) is responsible for capturing the $\mathrm{CO}_{2}$ from flue gas. A portable amine plant developed in cooperation with Tauron through a previous project [172][174] will be used. West Technology \& Trading Polska Sp. will integrate the methanation reactor and auxiliary equipment [172], whilst Rafako S.A. will evaluate a potential commercialization. The project has been funded through KIC InnoEnergy [170].

3.13. Desert Research Institute $-\mathrm{CO}_{2}$ recycling via reaction with hydrogen 
In 2009, the Desert Research Institute (DRI), with financial support from RCO2 AS, built a lab-scale reactor to demonstrate the feasibility of catalytic methanation. The system was installed in a portable trailer in Reno, United States [175].

A cylindrical vessel, made of $304 \mathrm{~L}$ stainless steel, acted as reactor; it was $16.5 \mathrm{~cm}$ long, with an outer diameter of $88.9 \mathrm{~mm}$ and a wall thickness of $4.6 \mathrm{~mm}$. The catalyst packed bed (PK-7R Haldor Topsoe) occupied 0.55 L, i.e. a length of $10.9 \mathrm{~cm}$. The gas flowed from top to bottom, and two thermocouples monitored the catalyst temperature [175] . A 5 kW PEM electrolyser, supplied by solar panels and wind turbines [176], produced high purity hydrogen (99.999 \%), at 13.8 bar, that was stored in four tanks with a total capacity of $0.1 \mathrm{~kg}$. Lastly, the carbon dioxide source was a gas mixture of $2 \% \mathrm{CO}_{2}$ in $\mathrm{N}_{2}$, thus allowing various experimental conditions without excessive temperature rises. In fact, two 400-W band heaters had to be installed in the reactor to achieve the operating temperatures [175].

The optimal operating conditions were studied by varying the $\mathrm{H}_{2}: \mathrm{CO}_{2}$ ratio, the catalyst temperature and the space velocity. They found a maximum $60 \%$ conversion of $\mathrm{CO}_{2}$ in the range $300-350{ }^{\circ} \mathrm{C}$, using a $\mathrm{H}_{2}: \mathrm{CO}_{2}$ ratio of 4 , and a $10000 \mathrm{~h}^{-1}$ space velocity [175].

\subsection{HSR-IET - Power-to-Methane HSR}

The Institute for Energy Technology of the Hochschule für Technik Rapperswil (HSRIET) has built and put in operation the first Swiss Power to Gas facility, located in Rapperswil. The Pilot- und Demonstrationsanlage Power-to-Methane HSR project focuses on developing simulation models and plant designs through experimentation for assessing the future role of Power to Gas in the Swiss energy supply [177]. The project 
started in November 2014, the plant opened in February 2015, and the final report should have been release in December 2015 [178].

The developed plant is an upgrade of the $25 \mathrm{~kW}$ prototype that ZSW operated in 2009 in collaboration with their spin-off ETOGAS [178]. The hydrogen is produced with renewable energy provided by the local power company Elektrizitätswerk JonaRapperswil AG (EWJR) [179], until a $50 \mathrm{~m}^{2}$ photovoltaic panel is installed. Moreover, the $\mathrm{CO}_{2}$ is captured from air, producing up to $4 \mathrm{~kg} /$ day [180]. In addition, for first time a Power to Gas plant will integrate the methanation heat in an ambient- $\mathrm{CO}_{2}$ absorption process [178].

The facility has a maximum output of $1 \mathrm{Nm}^{3} / \mathrm{h}$ of methane, which is finally compressed for a filling station (20 hours are needed to fill up a car tank) [178]. After 500 hours of operation, results show an efficiency of $35 \%$ without accounting the $\mathrm{CO}_{2}$ capture consumption -chemical energy contained in the compressed SNG per unit of electrical energy consumed in the facility [181].

Besides the HSR-IET, the consortium is formed by Audi, Climeworks, Erdgas Obersee, Erdgas Regio, and EWJR [178].

Thanks to the development of a pilot plant, the HSR-IET also participates in other two projects by providing experimental data and operating experience: Renewable Methane for Transport and Mobility (RMTM), and SCCER Storage project. The RMTM project focuses on the application of PtG technology through techno-economic assessment of its entire value chain [182]. It started in October 2015, with a time scope of three years and budgeted for $€ 1.0$ million. The Paul Scherrer Institute (PSI) is performing a life 
cycle analysis of the HSR-IET's PtG facility to quantify the environmental impact [183].

\subsection{HS Emden/Leer-EUTEC - Power to Gas in Emden}

The Emder Institute of Environmental Engineering of the Hochschule Emden/Leer (HS Emden/Leer-EUTEC) evaluated the suitability of a wastewater treatment plant as $\mathrm{CO}_{2}$ supplier for Power to Gas. The project was launched in 2012 and developed during two years [184], including experimental research at lab-scale [185].

A facility was dimensioned during the project, comprising a $312 \mathrm{~kW}$ electrolyser and an isothermal reactor at $335{ }^{\circ} \mathrm{C}$ with a SNG production of $59 \mathrm{~m}^{3} / \mathrm{h}$ [185]. As a result, it was announced the construction of a pilot plant in the wastewater treatment plant of Emden [186], although no information about it progress has been released so far.

HS Emden/Leer-EUTEC led the project formed by the partners Stadtwerke Emden GmbH, Bau- und Entsorgungsbetrieb Emden (BEE), Thalen Consult, ibis Umwelttechnik GmbH, and Gesellschaft für Abwasserberatung und Management mbH (GA-Group) [184]. The budget amounted to $185 \mathrm{k} €$ and was funded with $125 \mathrm{k} €$ by the Ministerium für Wissenschaft und Kultur (MWK) through the European Regional Development Fund (ERDF) [187].

\subsection{Hitachi Zosen - $\mathrm{CO}_{2}$ Conversion to Methane Project}

$\mathrm{CO}_{2}$ Conversion to Methane Project, launched in 2012, aims to develop industrial PtG and construct the first facility in Thailand [188]. They proposed, as main application, to convert $\mathrm{CO}_{2}$ generated during extraction of natural gas from natural reservoirs [189].

The first phase of the project has been performed using tubular reactors of 5 meters long, with a $\mathrm{H}_{2}$ conversion of $99.3 \%$ operating at $200{ }^{\circ} \mathrm{C}$ [190]. The process employs 
ceramic catalyst based on zirconia-samarium, with nickel as active material, which was developed by Hashimoto et al. through previous research [191]. Thus, results have allowed the simulation and design of the plant that will be built in Thailand, with a methane production of $1000 \mathrm{Nm}^{3} / \mathrm{h}$ [188][192], between 2014 and 2016 [190]. Moreover, hydrogen will be produced by alkaline electrolysers [193] fed with desalinated seawater [191][192].

The partners cooperating in this research are Hitachi Zosen Corporation, Daiki Ataka Engineering Co. -a subsidiary of Hitachi- and PTT Exploration and Production Public Company Limited (PTTEP) -a Thai petroleum corporation- [191]. However, this project could not be possible without the research carried out by Hashimoto et al. in two prior projects since their technology is employed [194]:

- Prototype plant (1996): The Tohoku University developed the first worldwide Power to Gas prototype, located in the roof of its Institute for Materials Research (IMR). The facility comprises two reactor in series with an intermediate water removal [5], an electrolyser fed by a photovoltaic cell, and a $\mathrm{CH}_{4}$ combustor from which $\mathrm{CO}_{2}$ is recycled [194].

- Pilot plant (2002 - 2005): The prototype research was continued by the installation, in 2003, of an industrial pilot plant in the Tohoku Institute of Technology (TohTech). It producedup to $4 \mathrm{Nm}^{3} / \mathrm{h}$ of $\mathrm{H}_{2}$ and $1 \mathrm{Nm}^{3} / \mathrm{h}$ of $\mathrm{CH}_{4}$ [194]. This second project was funded through a 3-year grant for developing revolutionary technologies within the Millennium Projects framework [195].

\subsection{JKU Linz-EI - EE-Methan aus CO2 and OptFuel}


The Energy Institute of the Johannes Kepler University Linz (JKU Linz-EI) participates in four connected projects for developing an entire Power to Gas system in Austria [196]. Wind2Hydrogen (2014 - 2016) built a $100 \mathrm{~kW}$ pilot plant with 12 PEM electrolysers [197], EE-Methan aus $\mathrm{CO}_{2}(2013$ - 2016) develops catalytic methanation [198], OptFuel (2013 - 2016) focuses in biological methanation [199], and Underground Sun Storage (2013 - 2016) studies the storage of the generated gas [200][201] .

The main goal of EE-Methan aus $\mathrm{CO}_{2}$ project is to develop a ceramic honeycomb catalyst adapted to industrial $\mathrm{CO}_{2}$ sources for increasing lifetime a $10 \%$ with respect to commercial catalysts [202]. For testing, a methanation pilot plant was built in the University of Leoben consisting of three reactors in series with intermediate cooling. The operating window allows inlet temperatures up to $350{ }^{\circ} \mathrm{C}$ and pressures between 1 and 20 bar, with a maximum flow of $3 \mathrm{Nm}^{3} / \mathrm{h}$ [203][204]. Secondary objectives imply conditioning product gases by using membrane technology, environmental assessment and economic evaluation [205].

The second methanation project, OptFuel, focuses on hydrogen production through fermentation and on the purification requirements for its later conversion into methane. Minor goals as cost asessment and life-cycle analysis are also included [206]. The experimental methanation research is also performed at the pilot plant of MU Leoben, thus studying the potential of combining biological and chemical processes [204][207].

The consortium of the methanation projects is completed by the Vienna University of Technology (TU Wien), the Austrian Association for Gas and Water (ÖVGW), the Association of Gas and District Heating Supply Companies (FGW), Profactor GmbH, 
and the Christof Group. Moreover, the budgets amount to $780 \mathrm{k} €$ and $850 \mathrm{k} €$ for EEMethan aus $\mathrm{CO}_{2}$ and OptFuel, respectively [207][208].

\subsection{SoCalGas - P2G Solar Energy Storage}

The Southern California Gas Company (SoCalGas) is promoting Power to Gas in the United States with the first demonstrative project of the country that includes methanation. It is focused in enabling higher penetrations of solar power generation through its storage in the natural gas network. The project is located in Golden, Colorado, and scheduled from September 2014 to March 2016 [209].

The research takes place in the laboratories of the National Renewable Energy Laboratory (NREL), where a $150 \mathrm{~kW}$ electrolyser produces hydrogen under simulated photovoltaic profiles. The $\mathrm{CO}_{2}$ is transformed through biological methanation by single-cell methanogens in a liquid media reactor. Then, the product gas is used to produce electricity in a fuel cell [210].

The project is a joint research between SoCalGas, NREL and Electrochaea with a total budget of $900 \mathrm{k} \$$ equally co-funded [209][97]. In the future, SoCalGas intends to construct a pre-commercial demonstrator of $1 \mathrm{MW}$ [210].

\subsection{Paul Scherrer Institute - RENERG ${ }^{2}$}

The RENERG ${ }^{2}$ project (Renewable Energies for Future Energy Supply) focuses on transferring renewable energy surplus to mobility sector, studying electrolysis, methanation, combustion fundamentals, refueling and economics. The project began in 2013 and will be concluded by the end of 2016 [211][212][213].

Methanation research is conducted by the Paul Scherrer Institute through its bubbling fluidized bed methanator (GanyMeth), commissioned in April 2015 and placed in 
Switzerland. The reactor bed is $2 \mathrm{~m}$ high with a diameter of $21 \mathrm{~cm}$, withstanding pressures between 1 and 12 bar and producing up to $160 \mathrm{~kW}$ of SNG [214].

Experiments include dynamic load changes and feed gas variations for acting as a polygeneration of fuel, heat and electricity [212]. First tests utilize bottled gas that will be changed for real gases and a $100 \mathrm{~kW}$ PEM electrolyser when available. Expected results concern kinetics, hydrodynamics, catalyst abrasion and heat transfer [214].

The project consortium includes EMPA, the Swiss Federal Institute of Technology Zurich (ETH Zurich), the Zurich University of Applied Sciences (ZHAW), and EPFL. Budget amounts around $240 \mathrm{k} €$, funded by the Competence Center for Energy and Mobility (CCEM) [212][213].

\subsection{EMPA - Catalytic methanation of industrially-derived $\mathrm{CO}_{2}$}

The Swiss Federal Laboratories for Materials Science and Technology study the sorption enhanced methanation, which improves $\mathrm{CO}_{2}$ conversion by absorbing water in situ through a zeolite-nickel catalyst [215][216]. The process and reactor have been developed throughout three different projects focused on catalyst development (HyTech) [212], biogas upgrading (SmartCat) [217], and $\mathrm{CO}_{2}$ methanation (Catalytic methanation of industrially-derived $\mathrm{CO}_{2}$ ) [218].

Experiments are performed in a stainless steel reactor $45 \mathrm{~cm}$ long and $1.8 \mathrm{~cm}$ in diameter, operating at 1.2 bar with $13 \mathrm{~g}$ of catalyst. The space velocity is $1000 \mathrm{~h}^{-1}$ that corresponds to an output of $1 \mathrm{~kW}$ [215][216][219]. Currently, they evaluate the utilization of $\mathrm{CO}_{2}$ from the cement industry, and the issues of catalyst deactivation due to sulphur compounds, under the framework of the last mentioned project [218]. Moreover, the Laboratoire de photonique et interfaces of the Swiss Federal Institute of 
Technology in Lausanne (EPFL-LPI) assesses the production of renewable hydrogen through photo-electrochemical water splitting in a parallel project. Both lines of work belong to a collaborative joint of 5 individual projects that also covers fuel cells development and sustainability analyses (Joint project $\mathrm{CO}_{2}$ Reduction \& Use: Renewable fuels for efficient electricity production) [220].

EMPA has collaborated, throughout methanation projects, with ZHAW, EPFL and Zeochem AG [212][220][221]. The funds for the experimental facility came from the Swiss Federal Office of Energy (SmartCat project) and the SNSF (Catalytic methanation of industrially-derived $\mathrm{CO}_{2}$ project) [216].

\subsection{1. $\mathrm{BTU}-\mathrm{CO}_{2}$-Methanation of flue gas}

The Brandenburg University of Technology (BTU) researches on the methanation of oxyfuel $\mathrm{CO}_{2}$, conventional flue gas, and underground-stored $\mathrm{CO}_{2}$, besides studying the influence of contaminants like $\mathrm{SO}_{\mathrm{x}}$ or $\mathrm{NO}_{\mathrm{x}}$. Their last project $\left(\mathrm{CO}_{2}\right.$-Methanation of flue gas), which concluded in October 2015, included a 3 month trial operation at Schwarze Pumpe power plant, in Germany [222][223].

The Power to Gas pilot consists of two parallel methanators which are $153 \mathrm{~mm}$ in diameter, $870 \mathrm{~mm}$ high and have 15 slots for temperature measurements [224]. Total volume reactor amounts to $30 \mathrm{dm}^{3}$ and contains up to $2 \mathrm{~kg}$ of catalyst (Ni $66 \% \mathrm{w}$ on Silica/Alumina). The pilot plant works at $350{ }^{\circ} \mathrm{C}$ and 10 bar, with an input capacity of $1200 \mathrm{Nm}^{3} /$ day thus producing about $200 \mathrm{Nm}^{3} /$ day of $\mathrm{CH}_{4}$ [225]. $\mathrm{H}_{2}$ is supplied from bottles although it was proposed the implementation of a PEM electrolyser in the future [224]. Results show conversions above $80 \%$ and selectivity between 90 and $100 \%$ [225]. 
Panta Rhei GmbH and Vattenfall Europe Generation AG joined as partners, whilst the BMWi supported the project with $565 \mathrm{k} €$ [223][226]. Previously, the Brandenburg University of Technology accomplished three projects concerning lab scale tests and upscaling:

- GeoEn (2011 - 2013): As part of this project, BTU studied the stability of catalysts against $\mathrm{SO}_{\mathrm{x}}$ and $\mathrm{NO}_{\mathrm{x}}$ in the context of oxyfuel process [227]. The lab facility consists of a reactor tube, $8 \mathrm{~mm}$ in diameter and $100 \mathrm{~mm}$ in length, mounted into an oven that supplies homogeneous temperature distribution during reaction. As catalysts, they used $\mathrm{NiO}$ supported on silica gel and $\mathrm{RuO}_{2}$ on alumina. BMBF supported financially the joint research in which also participated the German Research Centre for Geosciences (GFZ) and the University of Potsdam [228][229].

- $\mathrm{CO}_{2}$ catalysis, pilot plant I \& II (2011 - 2014): During this two-phase project, the BTU upgraded the lab facility into the pilot plant employed later in their research [225][230]. The project was funded with about $605 \mathrm{k} €$ from the European Regional Development Fund through the Ministerium für Wissenschaft, Forschung und Kultur (MWFK) [231].

\subsection{Columbia University - Dual function materials for $\mathrm{CO}_{2}$ capture and conversion}

The Columbia University in the City of New York, with financial support from BASF, researches on dual function materials that capture $\mathrm{CO}_{2}$ from an emission source and convert it to synthetic natural gas in the same reactor and at the same temperature, by using renewable $\mathrm{H}_{2}$ [232]. 
The related publications range from 2013 to 2015 covering the process parameters, cyclic stability tests, and kinetic characterization of methanation through a $10 \% \mathrm{Ru} / \gamma$ $\mathrm{Al}_{2} \mathrm{O}_{3}$ catalyst [233][234], in addition to feasibility studies of the dual function material consisting of $1-11 \% \mathrm{w}$ Ru and $1-10 \% \mathrm{w} \mathrm{CaO}$ dispersed on $\gamma-\mathrm{Al}_{2} \mathrm{O}_{3}$ carrier [232] . As methanator they used a fixed bed glass reactor with an inner diameter of $12 \mathrm{~mm}$ at a pressure of $1 \mathrm{~atm}$ [234].

\subsection{BTU-FESPE - Biocatalytic methanation in an anaerobic three-phase system}

The Faculty of Environmental Science and Process Engineering of the Brandenburg University of Technology (BTU-FESPE) has developed an anaerobic trickle-bed reactor for biocatalytic methanation at $37^{\circ} \mathrm{C}$ and ambient pressure in a continuous process. Their last prototype includes an electrolyser for $\mathrm{H}_{2}$ generation and conventional $\mathrm{CO}_{2}$ pressure cylinders, although it can also enrich a biogas source [235].

The reactor is $141 \mathrm{~cm}$ in length and $28.2 \mathrm{~cm}$ in diameter, with a total volume of $88 \mathrm{~L}$. It contains a fixed-bed of random packing material with a high specific surface area on which microorganisms can be immobilized and surrounded by gas phase. Then, they are sprinkled with liquid thus creating greater concentration gradients and improving the driving force for the mass transfer. Results show methane outputs of $98 \%$ in a single reactor without necessity for gas recirculation [235].

Once the detailed information has been described for each individual PtG project, the technical information is filtered and presented in the following tables to facilitate the comparison between operation parameters. Table 3 includes those projects in which CO2 methanation is carried out through a catalytic process.

Table 3. Technical parameters of PtG projects with catalytic methanation. 


\begin{tabular}{|c|c|c|c|c|c|c|c|c|c|}
\hline Project Name & $\begin{array}{c}\text { Reacto } \\
\text { r }\end{array}$ & $\begin{array}{c}\text { Temperatur } \\
\text { e }\left[{ }^{\circ} \mathrm{C}\right]\end{array}$ & $\begin{array}{l}\text { Pressur } \\
\text { e [bar] }\end{array}$ & $\begin{array}{c}\text { Electrolyse } \\
\text { r [kWe] }\end{array}$ & $\begin{array}{c}\text { Electrolyse } \\
\mathbf{r} \\
\text { Technolog } \\
\mathbf{y} \\
\end{array}$ & $\begin{array}{c}\text { Efficienc } \\
\text { y PtG } \\
{[\%]}\end{array}$ & $\begin{array}{c}\text { Output } \\
{[\mathrm{Nm} 3 / \mathrm{h}} \\
]\end{array}$ & $\begin{array}{c}\text { Methan } \\
\text { e } \\
\text { content } \\
{[\%]} \\
\end{array}$ & Ref. \\
\hline Audi e-gas & $\begin{array}{c}\text { Isotherm } \\
\text { al fixed } \\
\text { bed }\end{array}$ & - & - & 6000 & Alkaline & 54 & 325.0 & - & $\begin{array}{l}\text { [74], } \\
{[77]}\end{array}$ \\
\hline HELMETH & - & 300 & 30 & 15 & SOEC & - & 5.4 & - & $\begin{array}{c}{[116]} \\
, \\
{[123]}\end{array}$ \\
\hline $\begin{array}{c}\text { MeGa-stoRE - } \\
\text { Methane Gas } \\
\text { storage of } \\
\text { Renewable } \\
\text { Energy }\end{array}$ & $\begin{array}{c}\text { Air- } \\
\text { cooled }\end{array}$ & 270 & 8 & - & $\begin{array}{l}\text { Bottled } \\
\text { hydrogen }\end{array}$ & - & - & $\begin{array}{c}97.0- \\
99.0\end{array}$ & [139] \\
\hline RENOVAGAS & $\begin{array}{c}\text { Multicha } \\
\text { nnel }\end{array}$ & $275-330$ & 25 & 15 & Alkaline & - & 2.0 & - & $\begin{array}{c}{[146]} \\
\quad \\
{[147]}\end{array}$ \\
\hline P2G project & $\begin{array}{c}\text { Fixed } \\
\text { bed }\end{array}$ & $150-700$ & $8-15$ & 7 & PEM & - & - & - & $\begin{array}{c}{[148]} \\
\quad \\
{[151]}\end{array}$ \\
\hline $\begin{array}{c}\text { Synthetic } \\
\text { methane: a } \\
\text { medium for } \\
\text { storage and } \\
\text { transportation of } \\
\text { excess renewable } \\
\text { energy }\end{array}$ & - & $230-240$ & 6 & $\mathrm{n} / \mathrm{a}$ & $\begin{array}{c}\text { Bottled } \\
\text { hydrogen }\end{array}$ & - & - & - & $\begin{array}{c}{[153]} \\
, \\
{[156]} \\
, \\
{[157]}\end{array}$ \\
\hline DemoSNG & $\begin{array}{c}\text { Honeyco } \\
\mathrm{mb}\end{array}$ & $<300$ & - & $\mathrm{n} / \mathrm{a}$ & PEM & - & - & - & $\begin{array}{c}{[160]} \\
, \\
{[163]}\end{array}$ \\
\hline $\begin{array}{l}\text { Storage of } \\
\text { electric energy } \\
\text { from renewable } \\
\text { sources in the } \\
\text { natural gas grid - } \\
\text { water electrolysis } \\
\text { and synthesis of } \\
\text { gas components }\end{array}$ & $\begin{array}{l}\text { Fixed } \\
\text { bed / } \\
\text { Slurry }\end{array}$ & - & - & 6 & PEM & - & - & - & $\begin{array}{c}{[165]} \\
, \\
{[167]}\end{array}$ \\
\hline CO2-SNG & $\begin{array}{c}\text { Structure } \\
\text { d }\end{array}$ & - & - & - & - & - & - & - & $\begin{array}{c}{[170]} \\
, \\
{[173]} \\
, \\
{[174]}\end{array}$ \\
\hline $\begin{array}{c}\mathrm{CO}_{2} \text { recycling via } \\
\text { reaction with } \\
\text { hydrogen } \\
\end{array}$ & $\begin{array}{c}\text { Fixed } \\
\text { bed }\end{array}$ & $300-350$ & - & 5 & PEM & - & - & - & $\begin{array}{c}{[175]} \\
{[176]} \\
\end{array}$ \\
\hline $\begin{array}{l}\text { Kommunale } \\
\text { Kläranlagen als } \\
\text { Energiespeicher }\end{array}$ & $\begin{array}{l}\text { Isotherm } \\
\text { al }\end{array}$ & 335 & - & 312 & - & - & 59.0 & - & $\begin{array}{c}184] \\
, \\
{[185]} \\
, \\
{[186]}\end{array}$ \\
\hline $\begin{array}{c}\mathrm{CO}_{2} \text { Conversion } \\
\text { to Methane } \\
\text { Project } \\
\end{array}$ & $\begin{array}{c}\text { Fixed } \\
\text { bed }\end{array}$ & 200 & - & $\mathrm{n} / \mathrm{a}$ & Alkaline & - & 1000.0 & - & $\begin{array}{c}{[188]} \\
, \\
{[190]} \\
\end{array}$ \\
\hline $\begin{array}{c}\text { Pilot plant - } \\
\text { Tohoku Institute } \\
\text { of Technology }\end{array}$ & - & - & - & $\mathrm{n} / \mathrm{a}$ & Alkaline & - & 1 & - & $\begin{array}{c}{[194]} \\
\quad \\
{[195]} \\
\end{array}$ \\
\hline $\begin{array}{c}\text { Prototype plant - } \\
\text { Tohoku } \\
\text { University }\end{array}$ & - & - & - & $\mathrm{n} / \mathrm{a}$ & Alkaline & - & - & - & $\begin{array}{c}{[194]} \\
, \\
{[195]}\end{array}$ \\
\hline $\begin{array}{l}\text { EE-Methan from } \\
\text { CO2 }\end{array}$ & $\begin{array}{c}\text { Honeyco } \\
\mathrm{mb}\end{array}$ & $>350$ & $1-20$ & - & - & - & 3 & - & $\begin{array}{c}{[198]} \\
, \\
{[203]} \\
, \\
{[204]} \\
\end{array}$ \\
\hline $\begin{array}{c}\text { Catalytic } \\
\text { methanation of } \\
\text { industrially- } \\
\text { derived } \mathrm{CO}_{2} \\
\end{array}$ & $\begin{array}{c}\text { Fixed } \\
\text { bed }\end{array}$ & - & 1.2 & - & $\operatorname{PEC}(*)$ & - & 0.1 & - & $\begin{array}{l}{[218]} \\
\text { [221] }\end{array}$ \\
\hline SmartCat & - & - & - & - & $\begin{array}{l}\text { Bottled } \\
\text { hydrogen }\end{array}$ & - & - & - & $\begin{array}{l}{[217]} \\
, \\
{[219]}\end{array}$ \\
\hline HyTech & - & - & - & - & $\begin{array}{c}\text { Bottled } \\
\text { hydrogen }\end{array}$ & - & - & - & [212] \\
\hline $\begin{array}{c}\mathrm{CO}_{2} \text {-Methanation } \\
\text { of flue gas }\end{array}$ & $\begin{array}{c}\text { Fixed } \\
\text { bed }\end{array}$ & 350 & 10 & - & $\begin{array}{c}\text { Bottled } \\
\text { hydrogen }\end{array}$ & - & 200 & - & $\begin{array}{c}223] \\
\quad \\
{[224]} \\
, \\
{[226]}\end{array}$ \\
\hline $\mathrm{CO}_{2}$ catalysis, & Fixed & - & - & - & Bottled & - & - & - & [226] \\
\hline
\end{tabular}




\begin{tabular}{|c|c|c|c|c|c|c|c|c|c|}
\hline $\begin{array}{c}\text { pilot plant - } \\
\text { Technikum } 1 \text { \& } 2 \\
\end{array}$ & bed & & & & hydrogen & & & & [231] \\
\hline $\begin{array}{l}\text { Dual function } \\
\text { materials for } \mathrm{CO}_{2} \\
\text { capture and } \\
\text { conversion using } \\
\text { renewable } \mathrm{H}_{2}\end{array}$ & $\begin{array}{l}\text { Fixed } \\
\text { bed }\end{array}$ & - & 1 & - & $\begin{array}{l}\text { Bottled } \\
\text { hydrogen }\end{array}$ & - & - & - & $\begin{array}{r}{[233]} \\
, \\
{[234]} \\
\text { [235] }\end{array}$ \\
\hline
\end{tabular}

The projects with a biological methanation stage are gathered in Table 4 where their most relevant technical parameters are summarized.

Table 4. Technical parameters of PtG projects with biological methanation.

\begin{tabular}{|c|c|c|c|c|c|c|c|c|}
\hline Project Name & Reactor & $\begin{array}{c}\text { Temperature } \\
{\left[{ }^{\circ} \mathrm{C}\right]}\end{array}$ & $\begin{array}{c}\text { Pressure } \\
\text { [bar] }\end{array}$ & $\begin{array}{c}\text { Electrolyser } \\
\text { [kWe] }\end{array}$ & $\begin{array}{l}\text { Electrolyser } \\
\text { Technology }\end{array}$ & $\begin{array}{c}\text { Output } \\
\text { [Nm3/h] }\end{array}$ & $\begin{array}{c}\text { Methane } \\
\text { content } \\
{[\%]}\end{array}$ & Ref. \\
\hline POWERSTEP & - & - & - & - & - & - & - & $\begin{array}{r}{[97],} \\
{[104],} \\
{[105]}\end{array}$ \\
\hline $\begin{array}{l}\text { P2G-BioCat } \\
\text { project }\end{array}$ & $\begin{array}{l}\text { Liquid } \\
\text { phase }\end{array}$ & $60-65$ & - & 1000 & Alkaline & - & - & $\begin{array}{l}{[90],} \\
{[94],} \\
{[96]}\end{array}$ \\
\hline $\begin{array}{c}\text { Pre- } \\
\text { commercial }\end{array}$ & $\begin{array}{l}\text { Liquid } \\
\text { phase }\end{array}$ & - & - & 250 & PEM & - & - & $\begin{array}{l}{[100],} \\
{[102]}\end{array}$ \\
\hline $\begin{array}{c}\text { Industrial } \\
\text { Biogas Test }\end{array}$ & - & - & - & 1 & - & - & - & $\begin{array}{l}{[99],} \\
{[100]}\end{array}$ \\
\hline BioPower2Gas & - & - & - & 300 & PEM & - & - & $\begin{array}{l}{[107],} \\
{[108],} \\
{[109]}\end{array}$ \\
\hline $\begin{array}{c}\text { Mikrobielle } \\
\text { Methanisierung }\end{array}$ & - & - & - & 180 & PEM & - & - & $\begin{array}{l}{[114],} \\
{[115]}\end{array}$ \\
\hline $\begin{array}{l}\text { Power-to-Gas } \\
\text { im Eucolino }\end{array}$ & $\begin{array}{l}\text { Liquid } \\
\text { phase }\end{array}$ & - & - & 120 & - & 5.3 & 75.0 & $\begin{array}{l}\text { [73], } \\
{[112]}\end{array}$ \\
\hline $\begin{array}{c}\text { Biological } \\
\text { methanation of } \\
\text { pure streams }\end{array}$ & - & $40-65$ & - & 55 & - & - & - & {$[73]$} \\
\hline SYMBIO & $\begin{array}{l}\text { Anaerobic } \\
\text { digester }\end{array}$ & - & - & - & - & - & - & $\begin{array}{l}\text { [143], } \\
{[145]}\end{array}$ \\
\hline OptFuel & - & - & - & - & - & - & - & $\begin{array}{l}{[199],} \\
{[204],} \\
{[207]}\end{array}$ \\
\hline $\begin{array}{l}\text { P2G Solar } \\
\text { Energy Storage } \\
\text { RD\&D }\end{array}$ & $\begin{array}{l}\text { Liquid } \\
\text { phase }\end{array}$ & - & - & 150 & - & - & - & [209], \\
\hline $\begin{array}{l}\text { Biocatalytic } \\
\text { methanation in } \\
\text { an anaerobic } \\
\text { three-phase } \\
\text { system }\end{array}$ & $\begin{array}{l}\text { Anaerobic } \\
\text { trickle- } \\
\text { bed }\end{array}$ & 37 & 1 & - & - & - & 98.0 & $\begin{array}{l}{[236],} \\
{[237]}\end{array}$ \\
\hline
\end{tabular}


The projects in Table 2 which are not included in Tables 3 or 4 correspond to those projects whose methanation process is not clearly defined in open literature.

\section{Conclusions}

Because of worldwide renewable energy penetration targets, massive energy storage concepts have taken significance during recent years. Power to Gas seems to tackle this issue not only in terms of energy storage but also in $\mathrm{CO}_{2}$ utilization. A large number of researchers has revisited PtG technology in the last decade with energy storage purposes to better integrate renewable sources in the system. A remarkable increase in technology deployment in terms of ongoing projects dealing with 3step-PtG processes started after 2010 and currently available information predicts that this period will last, at least, until 2025.

Although the first pilot plant was erected in Japan, the current leadership holds in Europe, mainly thanks to the support of the governments of Germany, Denmark and Switzerland. These experiences combine pilot and demonstration plants whose electrolyzer sizes vary from few $\mathrm{kW}_{\mathrm{e}}$ (lab-scale plants) to 3x2.0 $\mathrm{MW}_{\mathrm{e}}$ (largest existing plant). USA has also contributed to the deployment of the technology with up to four projects since 2009. Data show that the average budgets for demo-plants projects are around one million euro per year in most cases.

Regarding methanation technologies, large projects cover mainly catalytic processes due to its scale up capability, although recently some biological projects also rose up to the $\mathrm{MW}$ range. Current pilot plants prefer biogas as source of $\mathrm{CO}_{2}$ since the energy penalty associated to carbon capture vanishes. For the same reason, syngas upgrading emerges as a future suitable option. Few others have experienced with more innovative 
$\mathrm{CO}_{2}$ sources such as industrial processes, the atmosphere, natural gas extraction processes or wastewater treatment plants.

There is large room for further investigation to address the real potential of this technology as a system for decarbonizing natural gas. Future research must focus on the study of new sources of $\mathrm{CO}_{2}$ which present low energy penalty and a renewable origin in order to completely close the $\mathrm{CO}_{2}$ cycle. Furthermore, it must be tackled the current high costs of this kind of systems, and the necessity of optimize the heat management for a possible cogeneration or trigeneration integration that increases the global efficiency of the process.

\section{Acknowledgements}

The authors would like to acknowledge funding from Fundación Iberdrola through the program “Ayudas a la Investigación en Energía y Medioambiente” 2014-2015. Financial support for M.B. during her Ph.D. studies was provided by the Department of Industry and Innovation of Diputación General de Aragón.

\section{Annex A. List of institutions/companies and abbreviations}

$\begin{array}{ll}\text { Abbreviation } & \text { Institution } \\ \text { AAU } & \text { Aalborg University } \\ \text { AB InBev } & \text { Anheuser-Busch InBev NV/SA } \\ \text { Abengoa } & \text { Abengoa Hidrógeno } \\ \text { AGH-UST } & \text { AGH University of Science and Technology } \\ \text { AgroPark } & \text { Agro Business Park A/S } \\ \text { APS } & \text { Aqua Plant Solutions GmbH } \\ \text { Arctik } & \text { Arctik SPRL } \\ \text { Atemis } & \text { Atemis GmbH } \\ \text { Atmostat } & \text { Atmostat } \\ \text { AU } & \text { Aarhus University } \\ \text { AU Herning } & \text { Aarhus University Department of Business Development and } \\ & \text { Technology } \\ \text { Audi } & \text { Audi AG } \\ \text { Avedøre-WWTP } & \text { Avedøre Wastewater Treatment Plant }\end{array}$




\begin{tabular}{|c|c|}
\hline$A V L$ & AVL GmbH \\
\hline BASF & BASF \\
\hline$B E E$ & Bau- und Entsorgungsbetrieb Emden \\
\hline$B F P$ & Studio Tecnico BFP srl \\
\hline Biofos & Biofos A/S \\
\hline$B M B F$ & Federal Ministry of Education and Research \\
\hline$B M U B$ & $\begin{array}{l}\text { Federal Ministry for the Environment, Nature Conservation, } \\
\text { Building and Nuclear Safety }\end{array}$ \\
\hline$B M W F J$ & Bundesministeriums für Wirtschaft, Familie und Jugend \\
\hline$B M W i$ & Federal Ministry for Economic Affairs and Energy \\
\hline$B T U$ & Brandenburg University of Technology \\
\hline BTU-FESPE & $\begin{array}{l}\text { Faculty of Environmental Sciences and Process Engineering of the } \\
\text { Brandenburg University of Technology }\end{array}$ \\
\hline$B W B$ & Berliner Wasserbetriebe \\
\hline Carbotech & Carbotech \\
\hline CAS & Chinese Academy of Science \\
\hline CCEM & Competence Center for Energy and Mobility \\
\hline CEA & Atomic Energy and Alternative Energies Commission \\
\hline Cemtec & Cemtec \\
\hline Chalmers & Chalmers University of Technology \\
\hline Christof Group & Christof Group \\
\hline Climeworks & Climeworks \\
\hline CNH2 & National Centre for Hydrogen and Fuel Cell Technology \\
\hline Columbia University & The Columbia University in the City of New York \\
\hline Cortus & Cortus \\
\hline CUBE & CUBE \\
\hline$D A E$ & Daiki Ataka Engineering Co., Ltd. \\
\hline DBFZ & German Biomass Research Center \\
\hline$D B I-G U T$ & DBI Gas-und Umwelttechnik GmbH \\
\hline$D E A$ & Danish Energy Agency \\
\hline$D G C$ & Danish Gas Technology Centre \\
\hline$D N V G L$ & DNV GL Group \\
\hline DONG & DONG Energy \\
\hline$D R I$ & Desert Research Institute \\
\hline DTU & Technical University of Denmark \\
\hline DTU-Environment & $\begin{array}{l}\text { Technical University of Denmark - Department of Environmental } \\
\text { Engineering }\end{array}$ \\
\hline DTU-Mekanik & $\begin{array}{l}\text { Technical University of Denmark - Department of Mechanical } \\
\text { Engineering }\end{array}$ \\
\hline DVGW & Deutscher Verein des Gas- und Wasserfaches e.V. \\
\hline$D V G W-E B I$ & $\begin{array}{l}\text { Deutscher Verein des Gas- und Wasserfaches e.V. Forschungsstelle } \\
\text { at the Engler-Bunte Institute of KIT }\end{array}$ \\
\hline E.ON & E.ON AG \\
\hline$E a$ & Ea Energianalyse A/S \\
\hline EAM EnergiePlus & EAM EnergiePlus GmbH \\
\hline Eawag & Swiss Federal Institute of Aquatic Science and Technology \\
\hline ECN & Energy Research Centre of the Netherlands \\
\hline EDI & Energy Delta Institute \\
\hline
\end{tabular}




\begin{tabular}{|c|c|}
\hline EII Spa & Engineering Ingegneria Informatica SPA \\
\hline Electrochaea & Electrochaea $\mathrm{GmbH}$ \\
\hline Elplatek & Elplatek A/S \\
\hline EMPA & Swiss Federal Laboratories for Materials Science and Technology \\
\hline Enagas & Enagás S.A. \\
\hline$E n B W$ & Energie Baden-Württemberg AG \\
\hline Energie $360^{\circ}$ & Energie $360^{\circ} \mathrm{AG}$ \\
\hline EnergieNetz & EnergieNetz Mitte GmbH \\
\hline EnergiMidt & EnergiMidt \\
\hline Energinet.dk & Energinet.dk \\
\hline Energy Valley & Stichting Energy Valley \\
\hline EPFL & Swiss Federal Institute of Technology in Lausanne \\
\hline EPFL-CEN & $\begin{array}{l}\text { Energy Center of the Swiss Federal Institute of Technology in } \\
\text { Lausanne }\end{array}$ \\
\hline EPFL-IPESE & $\begin{array}{l}\text { Industrial Process and Energy Systems Engineering of the Swiss } \\
\text { Federal Institute of Technology in Lausanne }\end{array}$ \\
\hline EPFL-LMER & $\begin{array}{l}\text { Laboratory of Materials for Renewable Energy of the Swiss Federal } \\
\text { Institute of Technology in Lausanne }\end{array}$ \\
\hline$E P F L-L P I$ & $\begin{array}{l}\text { Laboratoire de photonique et interfaces of the Swiss Federal } \\
\text { Institute of Technology in Lausanne }\end{array}$ \\
\hline Erdgas Obersee & Erdgas Obersee AG \\
\hline Erdgas Regio & Erdgas Regio AG \\
\hline ERIC & European Research Institute of Catalysis AISBL \\
\hline ETH Zurich & Swiss Federal Institute of Technology Zurich \\
\hline ETOGAS & ETOGAS GmbH \\
\hline EWE Biogas & EWE Biogas GmbH \& Co. KG \\
\hline EWJR & Elektrizitätswerk Jona-Rapperswil AG \\
\hline EWZ & Elektrizitätswerk der Stadt Zürich \\
\hline FCC-Aqualia & FCC-Aqualia S.A. \\
\hline FENES & Research Center for Power Grids and Energy Storage \\
\hline FFG & Austrian Research Promotion Agency \\
\hline$F G W$ & Association of Gas and District Heating Supply Companies \\
\hline Fraunhofer IPM & Fraunhofer Institue for Physical Measurement Techniques \\
\hline Fraunhofer ISE & Fraunhofer Institute for Solar Energy Systems \\
\hline Fraunhofer IWES & $\begin{array}{l}\text { Fraunhofer Institute for Wind Energy and Energy System } \\
\text { Technology }\end{array}$ \\
\hline GA-Group & Gesellschaft für Abwasserberatung und Management mbH \\
\hline Gas Natural Fenosa & Gas Natural Fenosa \\
\hline GFZ & German Research Centre for Geosciences \\
\hline GreenHydrogen & GreenHydrogen.dk \\
\hline Haldor Topsoe & Haldor Topsoe A/S \\
\hline Hanze UAS & Hanze University of Applied Sciences \\
\hline HBFZ & Hessian Biogas Research Centre \\
\hline HIRC & Hydrogen Innovation \& Research Center \\
\hline Hitachi Zosen & Hitachi Zosen Corporation \\
\hline HMN Gashandel & HMN Gashandel A/S \\
\hline HMN Naturgas & HMN Naturgas I/S \\
\hline HMUELV & Hessian Ministry of the Environment, Climate Protection, \\
\hline
\end{tabular}




\begin{tabular}{|c|c|}
\hline Hokudai & Hokkaido University \\
\hline HS Emden/Leer & Hochschule Emden/Leer \\
\hline HS Emden/Leer-EUTEC & $\begin{array}{l}\text { Emder Institute of Environmental Engineering of the Hochschule } \\
\text { Emden/Leer }\end{array}$ \\
\hline HSR & Hochschule für Technik Rapperswill \\
\hline HSR-IET & $\begin{array}{l}\text { Institute for Energy Technology of the Hochschule für Technik } \\
\text { Rapperswil }\end{array}$ \\
\hline$H-\mathrm{Tec}$ & H-Tec Systems \\
\hline Hydrogenics & Hydrogenics \\
\hline ibis Umwelttechnik & ibis Umwelttechnik GmbH \\
\hline$I C h P W$ & Institute for Chemical Processing of Coal \\
\hline ICP-CSIC & Institute of Catalysis and Petrochemistry \\
\hline$I d E$ & Institute decentralised Energy Technologies \\
\hline$I M R$ & Institute for Materials Research of the Tohoku University \\
\hline INBIOM & Innovation Network For Biomass \\
\hline INSA & Institut national des sciences appliquées de Rouen \\
\hline Insero & Insero Business Services \\
\hline IoLiTec & Ionic Liquids Technologies GmbH \\
\hline JKU Linz & Johannes Kepler University Linz \\
\hline JKU Linz-EI & Energy Institute of the Johannes Kepler University Linz \\
\hline Juwi & Juwi AG \\
\hline KIT & Karlsruhe Institute of Technology \\
\hline KTH & KTH Royal Insitute of Technology \\
\hline$K W B$ & Berlin Centre of Competence for Water \\
\hline Lemvig Biogas & Lemvig Biogas Amba \\
\hline Maabjerg BioEnergy & Maabjerg BioEnergy A/S \\
\hline MES & Mitsui Engineering and Shipbuilding Co. \\
\hline MicrobEnergy & MicrobEnergy GmbH \\
\hline MINECO & Ministry of Economy and Competitiveness \\
\hline MIT & Massachusetts Institute of Technology \\
\hline MU Leoben & University of Leoben \\
\hline MWFK & Ministerium für Wissenschaft, Forschung und Kultur \\
\hline$M W K$ & Ministerium für Wissenschaft und Kultur \\
\hline NEAS & NEAS Energy \\
\hline NGF & Naturgas Fyn I/S \\
\hline NREL & National Renewable Energy Laboratory \\
\hline NRIM & National Research Institute for Metals \\
\hline NTUA & National Technical University of Athens \\
\hline$N U$ & Northwestern University \\
\hline Outotec & Outotec \\
\hline$\ddot{O V V G W}$ & Austrian Association for Gas and Water \\
\hline Panta Rhei & Panta Rhei GmbH \\
\hline PlanEnergi & PlanEnergi.dk \\
\hline PoliTo & Politecnico di Torino \\
\hline Profactor & Profactor GmbH \\
\hline PSI & Paul Scherrer Institute \\
\hline PTTEP & PTT Exploration and Production Public Company Limited \\
\hline
\end{tabular}




\begin{tabular}{|c|c|}
\hline Rafako & Rafako S.A. \\
\hline RCO2 AS & RCO2 AS \\
\hline Regio Energie & Regio Energie Solothurn \\
\hline$R U G$ & University of Groningen \\
\hline Ryoka & Ryoka Matthey Corporation \\
\hline SCCER-HaE & $\begin{array}{l}\text { Swiss Competence Center for Energy Research - Heat and } \\
\text { Electricity Storage }\end{array}$ \\
\hline Schmack & Schmack Biogas GmbH \\
\hline$S D U$ & University of Southern Denmark \\
\hline SFOE & Swiss Federal Office of Energy \\
\hline SNSF & Swiss National Science Foundation \\
\hline SoCalGas & Southern California Gas Company \\
\hline Stadtwerke Emden & Stadtwerke Emden GmbH \\
\hline Stedin & Stedin \\
\hline StMWi & $\begin{array}{l}\text { Bavarian Ministry of Economic Affairs, Infrastructure, Transport } \\
\text { and Technology }\end{array}$ \\
\hline Sunfire & Sunfire GmbH \\
\hline Sustec & Sustec Consulting \& Contracting BV \\
\hline Tauron & Tauron Group \\
\hline Tecnalia & Tecnalia \\
\hline Thalen Consult & Thalen Consult GmbH \\
\hline TKI Gas & TKI Gas \\
\hline TMLFUN & $\begin{array}{l}\text { Thuringian Ministry for Agriculture, Forestry, Environment and } \\
\text { Nature Conservation }\end{array}$ \\
\hline Tohoku University & Tohoku University \\
\hline TohTech & Tohoku Institute of Technology \\
\hline TS-Torino & Turbo Service Torino spa \\
\hline TU Berlin & Technische Universität Berlin \\
\hline TU Wien & Vienna University of Technology \\
\hline TU-Delft & Delft University of Technology \\
\hline$U B A$ & Umweltbundesamt \\
\hline Uchicago & The University of Chicago \\
\hline$U M$ & University of Montreal \\
\hline$U M-D M I$ & $\begin{array}{l}\text { University of Montreal - Department of Microbiology and } \\
\text { Immunology }\end{array}$ \\
\hline Uni-Postdam & University of Potsdam \\
\hline Uni-Regensburg & Universität Regensburg \\
\hline Vattenfall & Vattenfall Europe Generation AG \\
\hline Veolia & Veolia Deutschland GmbH \\
\hline Veolia-WT & Veolia Water Technologies AB \\
\hline Viessmann & Viessmann Group \\
\hline VSG & Verband der Schweizerischen Gasindustrie \\
\hline WT\&T Polska & West Technology \& Trading Polska Sp. Z o. o. \\
\hline Xergi & Xergi A/S \\
\hline Zeochem & Zeochem AG \\
\hline ZHAW & Zurich University of Applied Sciences \\
\hline$Z S W$ & $\begin{array}{l}\text { Centre for Solar Power and Hydrogen Research Baden- } \\
\text { Württemberg }\end{array}$ \\
\hline
\end{tabular}




\section{References}

[1] Report from the Commission to the European Parliament, the Council, the European Economic and Social Committee and the Committee of the Regions Renewable energy progress report. Brussels: European Commission; 2015.

[2] Eurostat - Statistics Explained: Renewable energy statistics May 20152015. http://ec.europa.eu/eurostat/statistics-

explained/index.php/Renewable_energy_statistics (accessed January 12, 2015).

[3] Sterner M. Bioenergy and renewable power methane in integrated $100 \%$ renewable energy systems. Kassel university press GmbH, 2009.

[4] Hashimoto K. Metastable metals for "green" materials for global atmosphere conservation and abundant energy supply. Mater Sci Eng A 1994;179-180:2730 .

[5] Hashimoto K, Yamasaki M, Fujimura K, Matsui T, Izumiya K, Komori M, et al. Global CO2 recycling - novel materials and prospect for prevention of global warming and abundant energy supply. Mater Sci Eng A 1999;267:200-6.

[6] Ryckebosch E, Drouillon M, Vervaeren H. Techniques for transformation of biogas to biomethane. Biomass and Bioenergy 2011;35:1633-45.

[7] Higman C, van der Burgt M. Gasification Processes. In: Elsevier, editor. Gasification, Gulf Professional Publishing; 2008.

[8] Kopyscinski J, Schildhauer TJ, Biollaz SMA. Production of synthetic natural gas (SNG) from coal and dry biomass - A technology review from 1950 to 2009. Fuel 2010;89:1763-83.

[9] First ever large-scale demonstration biogas plant goes on-stream in Sweden with technology from Topsoe. Focus Catal 2015;2015:4.

[10] Rauch R, Hrbek J, Hofbauer H. Biomass gasification for synthesis gas production and applications of the syngas. WIREs Energy Environ 2013.

[11] Agersborg J, Lingehed E. Integration of Power-to-Gas in Gasendal and GoBiGas. Chalmers University of Technology, 2013.

[12] Gahleitner G. Hydrogen from renewable electricity: An international review of power-to-gas pilot plants for stationary applications. Int J Hydrogen Energy 2013:2039-61.

[13] Ball M, Weeda M. The hydrogen economy - Vision or reality? Int J Hydrogen Energy 2015:7903-19.

[14] Quadrelli EA, Centi G, Duplan J-L, Perathoner S. Carbon Dioxide Recycling: Emerging Large-Scale Technologies with Industrial Potential. ChemSusChem 2011;4:1194-215.

[15] Centi G, Quadrelli EA, Perathoner S. Catalysis for CO2 conversion: a key technology for rapid introduction of renewable energy in the value chain of chemical industries. Energy Environ Sci 2013;6:1711-31.

[16] Mikkelsen M, Jorgensen M, Krebs FC. The teraton challenge. A review of fixation and transformation of carbon dioxide. Energy Environ Sci 2010;3:43-81.

[17] Quintana N, Van der Kooy F, Van de Rhee MD, Voshol GP, Verpoorte R. 
Renewable energy from Cyanobacteria: energy production optimization by metabolic pathway engineering. Appl Microbiol Biotechnol 2011;91:471-90.

[18] Thiruvenkadam S, Izhar S, Yoshida H, Danquah MK, Harun R. Process application of Subcritical Water Extraction (SWE) for algal bio-products and biofuels production. Appl Energy 2015;154:815-28.

[19] Vo T-S, Ngo D-H, Kim S-K. Marine algae as a potential pharmaceutical source for anti-allergic therapeutics. Process Biochem 2012;47:386-94.

[20] Pulz O, Gross W. Valuable products from biotechnology of microalgae. Appl Microbiol Biotechnol 2004;65:635-48.

[21] Wang H-MD, Chen C-C, Huynh P, Chang J-S. Exploring the potential of using algae in cosmetics. Bioresour Technol 2015;184:355-62.

[22] Baroukh C, Muñoz-Tamayo R, Steyer J-P, Bernard O. A state of the art of metabolic networks of unicellular microalgae and cyanobacteria for biofuel production. Metab Eng 2015;30:49-60.

[23] Spolaore P, Joannis-Cassan C, Duran E, Isambert A. Commercial applications of microalgae. J Biosci Bioeng 2006;101:87-96.

[24] Václav K, Doubek J, Doucha J. The chlorococcalean alga Chlorella in animal nutrition: a review. J Appl Phycol 2015.

[25] Gudmundsson S, Nogales J. Cyanobacteria as photosynthetic biocatalysts: a systems biology perspective. Mol Biosyst 2015;11:60-70.

[26] Sakurai H, Masukawa H, Kitashima M, Inoue K. How Close We Are to Achieving Commercially Viable Large-Scale Photobiological Hydrogen Production by Cyanobacteria: A Review of the Biological Aspects. Life 2015;5:997-1018.

[27] Ola O, Maroto-Valer MM. Review of material design and reactor engineering on TiO2 photocatalysis for CO2 reduction. J Photochem Photobiol C Photochem Rev 2015;24:16-42.

[28] Chueh WC, Falter C, Abbott M, Scipio D, Furler P, Haile SM, et al. High-Flux Solar-Driven Thermochemical Dissociation of $\mathrm{CO} 2$ and $\mathrm{H} 2 \mathrm{O}$ Using Nonstoichiometric Ceria. Science 2010;330:1797-801.

[29] Roeb M, Neises M, Monnerie N, Sattler C, Pitz-Paal R. Technologies and trends in solar power and fuels. Energy Environ Sci 2011;4:2503-11.

[30] Agrafiotis C, Roeb M, Sattler C. A review on solar thermal syngas production via redox pair-based water/carbon dioxide splitting thermochemical cycles. Renew Sustain Energy Rev 2015;42:254-85.

[31] Albo J, Alvarez-Guerra M, Castaño P, Irabien A. Towards the electrochemical conversion of carbon dioxide into methanol. Green Chem 2015;17:2304-24.

[32] Qiao J, Liu Y, Hong F, Zhang J. A review of catalysts for the electroreduction of carbon dioxide to produce low-carbon fuels. Chem Soc Rev 2014;43:631-75.

[33] Kim B, Ma S, Molly Jhong H-R, Kenis PJA. Influence of dilute feed and pH on electrochemical reduction of $\mathrm{CO} 2$ to $\mathrm{CO}$ on $\mathrm{Ag}$ in a continuous flow electrolyzer. Electrochim Acta 2015;166:271-6.

[34] Bennamoun L, Afzal MT, Leonard A. Drying of alga as a source of bioenergy feedstock and food supplement - A review. Renew Sustain Energy Rev 2015;50:1203-12.

[35] Bharathiraja B, Chakravarthy M, Ranjith Kumar R, Yogendran D, Yuvaraj D, Jayamuthunagai J, et al. Aquatic biomass (algae) as a future feed stock for biorefineries: A review on cultivation, processing and products. Renew Sustain 
Energy Rev 2015;47:634-53.

[36] Chen G, Zhao L, Qi Y. Enhancing the productivity of microalgae cultivated in wastewater toward biofuel production: A critical review. Appl Energy 2015;137:282-91.

[37] Sarsekeyeva F, Zayadan BK, Usserbaeva A, Bedbenov VS, Sinetova MA, Los DA. Cyanofuels: biofuels from cyanobacteria. Reality and perspectives. Photosynth Res 2015;125:329-40.

[38] Song M, Duc Pham H, Seon J, Chul Woo H. Marine brown algae: A conundrum answer for sustainable biofuels production. Renew Sustain Energy Rev 2015;50:782-92.

[39] Sutherland DL, Howard-Williams C, Turnbull MH, Broady PA, Craggs RJ. Enhancing microalgal photosynthesis and productivity in wastewater treatment high rate algal ponds for biofuel production. Bioresour Technol 2015;184:222-9.

[40] Trentacoste EM, Martinez AM, Zenk T. The place of algae in agriculture: policies for algal biomass production. Photosynth Res 2015;123:305-15.

[41] Vijayakumar S, Menakha M. Pharmaceutical applications of cyanobacteria - A review. J Acute Med 2015;5:15-23.

[42] Han W, Clarke W, Pratt S. Composting of waste algae: A review. Waste Manag 2014;34:1148-55.

[43] Chow MC, Jackson WR, Chaffee AL, Marshall M. Thermal Treatment of Algae for Production of Biofuel. Energy \& Fuels 2013;27:1926-50.

[44] Razzak SA, Hossain MM, Lucky RA, Bassi AS, de Lasa H. Integrated CO2 capture, wastewater treatment and biofuel production by microalgae culturing - A review. Renew Sustain Energy Rev 2013;27:622-53.

[45] Menetrez MY. An Overview of Algae Biofuel Production and Potential Environmental Impact. Environ Sci Technol 2012;46:7073-85.

[46] Rosgaard L, de Porcellinis AJ, Jacobsen JH, Frigaard N-U, Sakuragi Y. Bioengineering of carbon fixation, biofuels, and biochemicals in cyanobacteria and plants. J Biotechnol 2012;162:134-47.

[47] Brennan L, Owende P. Biofuels from microalgae - A review of technologies for production, processing, and extractions of biofuels and co-products. Renew Sustain Energy Rev 2010;14:557-77.

[48] Kunjapur AM, Eldridge RB. Photobioreactor Design for Commercial Biofuel Production from Microalgae. Industrial and Engineering Chemistry Research 2010;49:3516-26.

[49] Mata TM, Martins AA, Caetano NS. Microalgae for biodiesel production and other applications: A review. Renew Sustain Energy Rev 2010;14:217-32.

[50] Das S, Wan Daud WMA. Photocatalytic CO2 transformation into fuel: A review on advances in photocatalyst and photoreactor. Renew Sustain Energy Rev 2014;39:765-805.

[51] Li K, An X, Park KH, Khraisheh M, Tang J. A critical review of CO2 photoconversion: Catalysts and reactors. Catal Today 2014;224:3-12.

[52] Liu L. Understanding the Reaction Mechanism of Photocatalytic Reduction of CO2 with $\mathrm{H} 2 \mathrm{O}$ on TiO2-Based Photocatalysts: A Review. Aerosol Air Qual Res 2014;14:453-69.

[53] Sun H, Wang S. Research Advances in the Synthesis of Nanocarbon-Based Photocatalysts and Their Applications for Photocatalytic Conversion of Carbon Dioxide to Hydrocarbon Fuels. Energy \& Fuels 2014;28:22-36. 
[54] Habisreutinger SN, Schmidt-Mende L, Stolarczyk JK. Photocatalytic reduction of $\mathrm{CO} 2$ on $\mathrm{TiO} 2$ and other semiconductors. Angew Chemie, Int Ed 2013;52:7372-7408.

[55] Izumi Y. Recent advances in the photocatalytic conversion of carbon dioxide to fuels with water and/or hydrogen using solar energy and beyond. Coord Chem Rev 2013;257:171-86.

[56] Tahir M, Amin NS. Advances in visible light responsive titanium oxide-based photocatalysts for CO2 conversion to hydrocarbon fuels. Energy Convers Manag 2013;76:194-214.

[57] Ganesh I. Conversion of Carbon Dioxide to Methanol Using Solar Energy - A Brief Review. Mater Sci Appl 2011;2:1407-15.

[58] Scheffe JR, Steinfeld A. Oxygen exchange materials for solar thermochemical splitting of H2O and CO2: a review. Mater Today 2014;17:341-8.

[59] Roeb M, Neises M, Monnerie N, Call F, Simon H, Sattler C, et al. MaterialsRelated Aspects of Thermochemical Water and Carbon Dioxide Splitting: A Review. Materials 2012;5:2015-54.

[60] Loutzenhiser PG, Meier A, Steinfeld A. Review of the Two-Step H2O/CO2Splitting Solar Thermochemical Cycle Based on Zn/ZnO Redox Reactions. Materials 2010;3:4922-38.

[61] Jones J-P, Prakash GKS, Olah GA. Electrochemical CO2 Reduction: Recent Advances and Current Trends. Isr J Chem 2014;54:1451-66.

[62] Lim RJ, Xie M, Sk MA, Lee J-M, Fisher A, Wang X, et al. A review on the electrochemical reduction of CO2 in fuel cells, metal electrodes and molecular catalysts. Catal Today 2014;233:169-80.

[63] Costentin C, Robert M, Savéant J-M. Catalysis of the electrochemical reduction of carbon dioxide. Chem Soc Rev 2013;42:2423-36.

[64] Jhong H-R, Ma S, Kenis PJA. Electrochemical conversion of CO2 to useful chemicals: current status, remaining challenges, and future opportunities. Curr Opin Chem Eng 2013;2:191-9.

[65] Kondratenko E V, Mul G, Baltrusaitis J, Larrazabal GO, Perez-Ramirez J. Status and perspectives of $\mathrm{CO} 2$ conversion into fuels and chemicals by catalytic, photocatalytic and electrocatalytic processes. Energy Environ Sci 2013;6:311235.

[66] Rittmann S, Seifert A, Herwig C. Essential prerequisites for successful bioprocess development of biological $\mathrm{CH} 4$ production from $\mathrm{CO} 2$ and $\mathrm{H} 2$. Crit Rev Biotechnol 2015;35:141-51.

[67] Götz M, Lefebvre J, Mörs F, McDaniel Koch A, Graf F, Bajohr S, et al. Renewable Power-to-Gas: A technological and economic review. Renew Energy 2016;85:1371-90.

[68] Rönsch S, Schneider J, Matthischke S, Schlüter M, Götz M, Lefebvre J, et al. Review on methanation - From fundamentals to current projects. Fuel 2016;166:276-96.

[69] Aziz M a. a., Jalil A a., Triwahyono S, Ahmad A. CO2 methanation over heterogeneous catalysts: recent progress and future prospects. Green Chem 2015;17:2647-63. doi:10.1039/C5GC00119F.

[70] Gao J, Liu Q, Gu F, Liu B, Zhong Z, Su F. Recent advances in methanation catalysts for the production of synthetic natural gas. RSC Adv 2015;5:22759-76. doi:10.1039/C4RA16114A. 
[71] Wang W, Wang S, Ma X, Gong J. Recent advances in catalytic hydrogenation of carbon dioxide. Chem Soc Rev 2011;40:3703-27.

[72] Ganesh I. Conversion of carbon dioxide into methanol - a potential liquid fuel: Fundamental challenges and opportunities (a review). Renew Sustain Energy Rev 2014;31:221-57.

[73] Benjaminsson G, Benjaminsson J, Rudberg RB. Power-to-Gas - A technical review. Svenskt Gastekniskt Center AB; 2013.

[74] Rieke S. Catalytic methanation - the Audi e-gas project as an example of industrialized technology for Power to gas. REGATEC 2015, Barcelona, Spain: 2015.

[75] Köbler J. Balanced mobility. Encounter - The Audi Technology Magazine 2011:36-41.

[76] Corporate Responsibility Report 2014: Audi e-gas-project - Life Cycle Assessment. Audi AG; 2014.

[77] Otten R. The first industrial PtG plant - Audi e-gas as driver for the energy turnaround. CEDEC Gas Day 2014, Verona, Italy: 2014.

[78] Strohbach O. Audi e-gas plant stabilizes electrical grid. Press Release - Audi MediaInfo - Technology and Innovation Communications 2015.

[79] Bosa T, Brusdeylins C, Regno A Del, Scherg G, Zimmer U. Anual Report 2014. Zentrum für Sonnenenergie- und Wasserstoff-Forschung Baden-Württemberg (ZSW); 2014.

[80] Forschungsjahrbuch Erneuerbare Energien 2012 - Forschungsberichte im Überblick. Bundesministerium für Umwelt, Naturschutz und Reaktorsicherheit; 2012.

[81] Persson T, Baxter D, editors. IEA Bioenergy Task 37 - Country Reports Summary 2014. IEA Bioenergy; 2014.

[82] Bosa T, Brusdeylins C, Regno A Del, Scherg G, Zimmer U. Anual Report 2013. Zentrum für Sonnenenergie- und Wasserstoff-Forschung Baden-Württemberg (ZSW); 2013.

[83] Power to Gas: Smart energy conversion and storage. Company presentation, Stuttgart, Germany: ETOGAS; 2013.

[84] Zuberbühler U, Specht M. Power-to-Gas: Construction and start-up of a $250 \mathrm{~kW}$ research plant. 7th International Renewable Energy Storage Conference, Berlin, Germany: 2012.

[85] Specht M. Power-to-Gas - Speicherung erneuerbarer Energie im Erdgasnetz. Fachsymposium “Erneuerbare Energien” - Inst. für Solarenergieforsch. Hameln, Emmerthal, Germany: Zentrum für Sonnenenergie- und Wasserstoff-Forschung Baden-Württemberg (ZSW); 2012.

[86] Iskov H, Rasmussen NB. Global screening of projects and technologies for Power-to-Gas and Bio-SNG. Danish Gas Technology Centre; 2013.

[87] Bard J, Braun M, Busmann HG, Bürkner F, Callies D, Caselitz P, et al. IWES Anual Report 2011/2012. Fraunhofer Institute for Wind Energy and Energy System Technology; 2012.

[88] Vartmann A. Weltweit größte Power-to-Gas-Anlage zur Methan-Erzeugung geht in Betrieb. Presse Release - PR-Agentur Solar Consulting GmbH 2012.

[89] Rieke S. Power-to-Gas technology - the missing link in renewable energy systems. Ecosummit, Berlin, Germany: 2012.

[90] Hofstetter D. Biocatalytic Methanation with Methanogenic Archaea for Power- 
to-Gas Energy Storage. Biomass for Swiss Energy Future Conference 2014, 2014.

[91] Hofstetter D. Energy storage leaders launch commercial scale power-to-gas project using highly innovative technology. Press Release - BioCat Project 2014.

[92] Denmark turns excess wind power into gas via HydHydrogen tech. Fuel Cells Bull 2014;2014:8-9.

[93] BioCat Kicks off construction phase at Avedore Wastewater Treatment Plant 2015. http://biocat-project.com/news/construction/ (accessed August 31, 2015).

[94] Energy Storage - Thematic Research Summary. European Commission; 2014.

[95] BioCat Project is still operating at full speed 2015 . http://biocatproject.com/news/biocat-project-is-still-operating-at-full-speed/ (accessed August 31, 2015).

[96] Hofstetter D. The BioCat Project - Lifting Biological Methanation to Market Readiness. REGATEC 2015, Barcelona, Spain: 2015.

[97] Hein M. Electrochaea at ECOSUMMIT. Ecosummit London 2015, London: 2015.

[98] STORE \& GO - Power-to-Gas - École Polytechnique Féderale de Lausanne 2015. http://energycenter.epfl.ch/store-go-en (accessed November 30, 2015).

[99] Martin MR, Fornero JJ, Stark R, Mets L, Angenent LT. A Single-Culture Bioprocess of Methanothermobacter thermautotrophicus to Upgrade Digester Biogas by CO2-to-CH4 Conversion with H2. Archaea 2013;2013:11.

[100] Hofstetter D. Biomethane Production via Power-to-Gas. UK Biomethane Day, Birmingham, United Kingdom: 2013.

[101] Grond L, Schulze P, Holstein J. Systems Analyses Power to Gas. Deliverable 1: Technology Review (TKI project TKIG01038). DNV KEMA; 2013.

[102] Adamsen APS. Three innovative methanation technologies - Aarhus University. Workshop for the promotion of biomethane in Denmarkm, Aarhus University; 2013.

[103] Hofstetter D. Erdgas Zürich and ewz to Partner with Electrochaea for Developing Breakthrough Power-to-Gas Technology. Press Release - Electrochaea Renewable Natural Gas 2013.

[104] Gonzalez AG. Climate action, environment, resource efficiency and raw materials. Horizon 2020 The EU Framework Programme for Research and Innovation. Catalogue of R\&I Projects. European Commission; 2014.

[105] Loderer C. POWERSTEP. Press Release - POWERSTEP Project 2015.

[106] Riechel M. Pressegespräch von DVGW und BDEW. Press Release - DVGW Im Congress Center West 2015.

[107] Heller T. First commercial PtG-plant with biological methanation goes live. HANNOVER MESSE - Technical Forum h2fc fair, Viessmann; 2015.

[108] Wusterhaus E. Feasibility of renewable natural gas projects - an international overview. REGATEC 2015, Barcelona, Spain: 2015.

[109] Schmack U. Wasserstoff biologisch methanisieren - Praxis und Perspektiven. Jahreskonferenz Power to Gas 2015, Berlin, Germany: 2015.

[110] Power-to-gas plant put into operation. Key technology to enter sustainable energy era. Press Release - Viessmann Werke GmbH \& Co KG 2015.

[111] Reuter M. Power to Gas: Microbial Methanation, a Flexible and Highly Efficient Method. HANNOVER MESSE, 2013.

[112] Agricola A-C. Die dena-Strategieplattform Power to Gas. BMBVS- 
Fachworkshop "Power-to-Gas: Beitrag zum nachhaltigen Verkehr," Berlin, Germany: Strategieplattform Power to Gas; 2013.

[113] Wasserstoff in den Fermenter. Perspektiven - Energie 2014:10-1.

[114] Reuter M. Viessmann Tochterunternehmen MicrobEnergy realisiert Power-toGas an der Kläranlage Schwandorf. Press Release - MicrobEnergy GmbH 2013.

[115] Mikrobielle Methanisierung - Speicherung elektrischer Überschussenergie durch Methansierung Kon Klärgas 2015. http://energieatlas.bayern.de/thema_biomasse/praxisbeispiele/details,704.html (accessed September 2, 2015).

[116] Programme Review Report 2014 - Fuel Cells and Hydrogen Joint Undertaking. Publications Office of the European Union; 2015. doi:10.2843/443072.

[117] von Olshausen C. Project Status - Liquid hydrhydrocarbon from CO2 and H2O and renewable electricity. BMBF Statusseminar, Berlin, Germany: Sunfire; 2015.

[118] Walter C. SOEC development status at sunfire GmbH. HANNOVER MESSE Technical Forum presentation, 2014.

[119] Krause, Müller-Syring G. Inventurliste der relevanten Forschungs- und DemoProjekte im Rahmen der Roadmap-Erstellung. Gastechnologisches Institut GmbH; 2014.

[120] Gruber M, Harth S, Trimis D, Bajohr S, Posdziech O, Brabandt J, et al. Integrated High-Temperature Electrolysis and Methanation for Effective Power to Gas Conversion (HELMETH). Gasfachliche Aussprachetagung, Essen, Germany: Karlsruher Institut für Technologie; 2015.

[121] Hochtemperatur-Dampfelektrolyse: Lösungstechnologie für die energiewende. Press Release - Sunfire 2015.

[122] Abate S, Mebrahtu C, Perathoner S, Gentiluomo S, Giorgianni G, Centi G. Catalytic Performance of Ni-based Catalysts Supported on $\gamma$-Al2O3-ZrO2-TiO2$\mathrm{CeO} 2$ Composite Oxide for CO2 Methanation. Proceedings of the 12th European Congress on Catalysis - EuropaCat-XI, Kazan, Russia: 2015.

[123] Landgraf M. Power to Gas: Storing the Wind and Sun in Natural Gas. Press Release - Karlsruhe Institute of Technology 2014.

[124] Energiforskning.dk. El upgraded biogas. Project Information 2015. http://energiforskning.dk/en/node/7155 (accessed September 9, 2015).

[125] Aktivitetsopfølgning - $\quad$ Status 1. marts 20142014. http://www.rm.dk/siteassets/vaekstforum/status/marts2014/aktivitetsopfolgningmarts-2014.pdf (accessed January 21, 2016).

[126] Hansen JB. Syngas Routes to Alternative Fuels from Renewable Sources. IEA Bioenergy Task 33 Workshop: Liquid Biofuels, Karlsruhe, Haldor Topsoe; 2014.

[127] Hansen JB, Petersen AS, Loncarevic I, Torbensen C, Korsgaard A, Christensen SL. GreenSynFuels - Final project Report. Danish Technological Institute; 2011.

[128] Vestervang S, Harder B, Jensen JB, Klüver K, Bjerre T, Gents J, et al. Energy 2011 - Annual report on Danish energy research programmes. Publication Office of the European Union; 2011.

[129] Biogas-SOEC Electrochemical upgrading of biogas to pipeline quality by means of SOEC electrolysis - Main Final Report ForskNG 2011 Project no. 10677. Haldor Topsoe; 2012.

[130] Slutrapport På Vej and Mod Metansamfundet? Fase 1 - Project Report. Midt RegionMidtJylland; 2012.

[131] Innovationsnetværk for brintteknologi (HIRC) - Handlingsplan opfølgning marts 
2011 n.d. https://www.rm.dk/siteassets/vaekstforum/handlingsplaner/opfolgningmarts-2011/hirc_slutevaluering-0311.pdf (accessed January 21, 2016).

[132] Held J. The methane platform: A-, B-, C-, E-, F- and L-methane. Nordic Biogas Conference, Renewable Energy Technology International AB; 2014.

[133] Pedersen CF. CO2 Electrofuels. Kick-off Event: Sustainable Energy Systems 2050, Helsinki, Finland: 2011.

[134] Energiforskning.dk. Green Natural Gas. Project Information 2015. http://energiforskning.dk/en/project/groen-naturgas (accessed September 10, 2015).

[135] Energianalyse.dk. Electrolysis by means of SOEC. Project Information 2015. http://www.ea-energianalyse.dk/projects-

english/1110_electrolysis_by_means_of_soec.html (accessed September 10, 2015).

[136] Topsoe Receives Funding from the Energy Technology Development and Demonstration Programme (EUDP). Catal Rev 2011;24:4.

[137] Energiforskning.dk. SYNFUEL - Sustainable synthetic fuels from biomass gasification and electrolysis. Project Information 2015. http://energiforskning.dk/node/8087 (accessed September 10, 2015).

[138] Nørgaard MS. Fremtidens vindmøllestrøm på lager i naturgasnettet 2012. http://auhe.au.dk/aktuelt/nyheder/nyhed/artikel/fremtidens-vindmoellestroempaa-lager-i-naturgasnettet/ (accessed September 11, 2015).

[139] Møller P, Yde L. MeGa-stoRE Final Report (Project no. 12006). Aarhus University; 2014.

[140] Energiforskning.dk. MeGa-stoRE - Methangas til lagring af VE. Project Information 2015. http://energiforskning.dk/node/7322 (accessed September 11, 2015).

[141] Energiforskning.dk. MeGa-stoRE - Optimering og opskalering. Project Information 2015. http://energiforskning.dk/node/8111 (accessed September 11, 2015).

[142] Yde L. Opnåede resultater i MeGa-stoRE-projektet og perspektivering. DGF’s Gastekniske Dage, Aarhus University; 2015.

[143] Energiforskning.dk. SYMBIO - Integration of biomass and wind power for biogas enhancement and upgrading via hydrogen assisted anaerobic digestion. Project Information 2015. http://energiforskning.dk/node/7267 (accessed September 16, 2015).

[144] Luo G, Johansson S, Boe K, Xie L, Zhou Q, Angelidaki I. Simultaneous hydrogen utilization and in situ biogas upgrading in an anaerobic reactor. Biotechnol Bioeng 2011;109:1088-94.

[145] SYMBIO project 2015. http://www.biogasupgrade.dk/ (accessed September 16, 2015).

[146] Sánchez M. RENOVAGAS - Proceso de Generación de Gas Natural Renovable. Jorn. PTEHPC. Grup. Trab. Técnico Almac. y Distrib. Hidrógeno, Huelva, Spain: Centro Nacional del Hidrógeno (CNH2); 2015.

[147] Pérez S, Sánchez M. Renovagas project - getting synthetic natural gas from renewable energy sources (RES). In: Held J, Schollenberger D, editors. Conference Proceedings of the 2nd International Conference on Renewable Energy Gas Technology, Barcelona, Spain: Renewable Energy Technology International AB; 2015. 
[148] Holstein J, Vlap H, van der Steen A, Grond L, Bos K. Experiences with one year operation of power-to-gas in Rozenburg, NL. In: Held J, Scholwin F, editors. Conference Proceedings of the 2nd International Conference on Renewable Energy Gas Technology, Barcelona, Spain: Renewable Energy Technology International AB; 2015.

[149] Power-to-Gas officieel geopend: elektriciteit wordt aardgas in Rozenburg 2014. http://www.tki-gas.nl/news/power-to-gas-officieel-geopend-elektriciteit-wordtaardgas-in-roz (accessed September 18, 2015).

[150] Power to Gas: methanation of hydrogen. Innovations in Energy 2012, 2012.

[151] Vlap H, van der Steen A, Knijp J, Holstein J, Grond L. Power-to-Gas project in Rozenburg, The Netherlands (Report No.; GCS.15.R24613, Rev. 0). DNV GL Oil \& Gas; 2015.

[152] Vlap H. Power-to-Gas Demonstration Project Rozenburg. Workshop Power2Gas: From Theory2Practice, 2014.

[153] Saric M, Dijkstra JW, Rabou LPLM, Haije WG, Walspurger S. SNG quality in Power to Gas applications. Sixth Research Day of the Energy Delta Gas Research, Nunspeet, The Netherlands: 2014.

[154] Synthetic methane: a medium for storage and transportation of excess renewable energy 2015. http://www.edgar-program.com/projects/c4 (accessed September 21, 2015).

[155] Special projects, Newsletter of the Energy Delta Gas Research - Number 10 2014. http://www.edgar-program.com/publications/newsletter/number-10-may2014 (accessed September 21, 2015).

[156] Saric M, Dijkstra JW, Walspurger S. Power-to-Gas coupling to biomethane production: a feasibility study. Proceedings of the 13th International Conference on Polygeneration Strategies, Vienna, Austria: 2013.

[157] Almansa GA, Rabou LPLM, van der Meijden CM, van der Drift A. ECN System for methanation (ESME). 23rd European Biomass Conference and Exhibition (EUBCE 2015), Vienna, Austria: ECN; 2015.

[158] Walspurger S, Elzinga GD, Dijkstra JW, Saric M, Haije WG. Sorption enhanced methanation for substitute natural gas production: Experimental results and thermodynamic considerations. Chem Eng J 2014;242:379-86.

[159] Landgraf M. Flexible Methane Production from Electricity and Bio-mass. Press Release - Karlsruhe Institute of Technology 2014.

[160] Engvall K. Bio-SNG produced in a PtG and biomass gasification system. Green Gas Research Outlook Sweden, Sweden: Energiforsk; 2015.

[161] Buchholz D. An optimised SNG production route. ENERGY NEWS - Newsletter of the KIT Energy Center 2014:9.

[162] Graf F. Power to Gas - state of the art and perspectives. MARCOGAZ - General Assembly: Workshop New Developments, DVGW Research Center at EnglerBunte-Institut of KIT; 2014.

[163] Buchholz D, Reimert R. An optimized SNG production route. Proceedings of World Bioenergy 2014, The Swedish Bioenergy Association; 2014.

[164] Gröschl F. Mastering future challenges with gas innovations - Intelligent technologies for the energy transition. DVGW Deutscher Verein des Gas- und Wasserfaches; 2014.

[165] Technologies for Sustainability and Climate Protection - Chemical Processes and Use of CO2 (Funding Programme Information Brochure). Federal Ministry of 
Education and Research (BMBF); 2014.

[166] Smolinka T. Methane Storage - Storage of Electric Energy from Renewable Sources in the Natural Gas Grid: H2O Electrolysis and Synthesis of Gas Components 2015. https://www.ise.fraunhofer.de/en/business-areas/systemintegration-and-grids-electricity-heat-gas/research-topics/power-togas/projects/methane-storage (accessed January 21, 2016).

[167] Schaaf T, Grünig J, Schuster MR, Rothenfluh T, Orth A. Methanation of CO2 storage of renewable energy in a gas distribution system. Energy Sustain Soc 2014;4:29.

[168] Lefebvre J, Götz M, Bajohr S, Reimert R, Kolb T. Improvement of three-phase methanation reactor performance for steady-state and transient operation. Fuel Process Technol 2015;132:83-90.

[169] Götz M, Lefebvre J, Schollenberger D, Bajohr S, Reimert R, Kolb T. Novel methanation concepts for the production of Substitute Natural Gas. International Gas Union Research Conference, Copenhagen: 2014.

[170] CO2-SNG. CO2 methanation system for electricity storage through SNG production 2015. http://www.kic-innoenergy.com/innovationproject/ourinnovation-projects/co2-sng/ (accessed September 28, 2015).

[171] Tauron chce metanizowac CO2, aby przechowywac energie z OZE 2015. http://www.bankier.pl/wiadomosc/Tauron-chce-metanizowac-CO2-abyprzechowywac-energie-z-OZE-3397346.html (accessed October 28, 2015).

[172] TAURON: Nowatorski projekt zagospodarowania CO2 juz w I kwartale 2017 r. Tauron Polska Energia 2015. http://media.tauron.pl/PressOffice/PressRelease.300328.po (accessed September 28, 2015).

[173] Liten Annual Report 2014. CEA Tech; 2014.

[174] Tatarczuk A. Pilot plant results for advanced CO2 capture process using AMP/PZ solvent at Tauron's coal-fired Power Plant. 3rd Post Combustion Capture Conference, 2015.

[175] Hoekman SK, Broch A, Robbins C, Purcell R. CO2 recycling by reaction with renewably-generated hydrogen. Int J Greenh Gas Control 2010;4:44-50.

[176] Robbins C, Hoekman SK, Broch A. CO2 Recycling by Reaction with Renewable-Generated Hydrogen. NHA Conference, Desert Research Institute; 2009.

[177] Friedl MJ, Meier B, Frank E, Crameri V, Cianelli C, Schmidlin L, et al. Pilot and Demonstration Plant Power-to-Methane, HSR. Heat and Electricity Storage 2nd Symposium - Book of Abstracts, Paul Scherrer Institute; 2015.

[178] Friedl M. Pilot- und Demonstrationsanlage Power-to-Methane HSR. Hochschule für Technik Rapperswil; 2015.

[179] Friedl M. HSR produziert Treibstoff aus Sonne, Wasser und CO2-Emissionen. Press Release - HSR Hochschule Für Tech Rapperswil 2014.

[180] Frank E. Aktivitäten Power-to-Gas am IET/HSR. Power-to-Gas Expert., Hochschule für Technik Rapperswil; 2015.

[181] Meier B. Power-to-Gas am Institut für Energietechnik. Power-to-Gas Expert., Hochschule für Technik Rapperswil; 2015.

[182] Friedl M. Methane for Transport and Mobility. Kick-off Meeting of NRPs 70 and 71 at the KKL, Hochschule für Technik Rapperswil; 2015.

[183] Schmidt TJ, Roth J, Elber U. SCCER HaE-Storage - Annual Activity Report 
2014. Swiss Competence Center for Energy Research - Heat and Electricity Storage; 2014.

[184] Steinigeweg S, Herrmann P. Kommunale Kläranlage als Energiespeicher 2015. http://www.hs-emden-leer.de/forschung-transfer/institute/eutec/arbeitsgruppeumweltverfahrenstechnik/projekte-in-der-ag-

umweltverfahrenstechnik/klaeranlagen-als-energiespeicher.html_ (accessed January 21, 2016).

[185] Steinigeweg S. Power to Gas in Emden. Sitzung 19.06.2013 Betriebsausschuss Bau- und Entsorgungsbetrieb, 2013.

[186] Schröder VH. Power to gas: Versuchsanlage in Planung. Ostfriesen Zeitung 2013.

[187] Grunau W. Kläranlagen als Energiespeicher. Press Release - Idw Informationsdienst Wissenschaft 2012.

[188] Weerawong A. CO2 Conversion to Methane Project. PTT Exploration and Production PCL; 2015.

[189] Annual Report 2014. Hitachi Zosen Corp; 2014.

[190] Demonstration of a new CO2-methanation process. Chem Eng 2014;121:16.

[191] Amouroux J, Siffert P, Pierre Massué J, Cavadias S, Trujillo B, Hashimoto K, et al. Carbon dioxide: A new material for energy storage. Prog Nat Sci Mater Int 2014;24:295-304.

[192] Hashimoto K. Carbon Dioxide to Methane via Electrolytic Hydrogen Generation for Intermittent Renewable Energy Supply. CEOP's Workshop at the E-MRS Spring Meeting 2015, Tohoku Institute of Technology; 2015.

[193] Tanisho T. Financial Results for the six months ended September. Hitachi Zosen Corporation IR Presentations, Hitachi Zosen Corp; 2014.

[194] Hashimoto K, Kumagai N, Izumiya K, Takano H, Kato Z. The production of renewable energy in the form of methane using electrolytic hydrogen generation. Energy Sustain Soc 2014;4:17.

[195] Hashimoto K, Yamasaki M, Meguro S, Sasaki T, Katagari H, Izumiya K, et al. Materials for global carbon dioxide recycling. Corros Sci 2002;44:371-86.

[196] REPORT 2014. Energieinstitut an der Johannes Keppler Universität Linz; 2014.

[197] Factsheet Forschungsprojekt wind2hydrogen. OMV Aktiengesellschaft; 2015.

[198] EE-Methan aus CO2 2015. http://www.energyefficiency.at/web/projekte/eemethan-aus-co2.html (accessed October 28, 2015).

[199] OptFuel - $\quad$ Energie Institut 2015. http://www.energyefficiency.at/web/projekte/optfuel.html (accessed October 28, 2015).

[200] Underground Sun Storage - Kick off Meeting 2015. http://www.undergroundsun-storage.at/en/news/detail/article/kick-off-meeting.html (accessed October 29, 2015).

[201] Power-to-Gas-Forschungsanlage Underground Sun.Storage mit Beteiligung des Energieinstituts eröffnet 2015. http://www.energyefficiency.at/web/projekte/power-to-gas-forschungsanlageunderground-sun.storage-mit-beteiligung-des-energieinstituts.html (accessed January 21, 2016).

[202] EE-Methan from CO2 - Development of a catalytic process for the methanation of $\quad \mathrm{CO} 2$ from industrial sources 2015. http://www.vt.tuwien.ac.at/thermal_process_engineering_and_simulation/comput 
ational_fluid_dynamics/projects/current_projects/ee_methan_from_co2_develop ment_of_a_catalytic_process_for_the_methanation_of_co2_from_industrial_sour ces/EN/ (accessed January 21, 2016).

[203] Biegger P, Felder AH, Lehner M. Entwicklung eines katalytischen Prozesses zur Methanisierung von CO2 aus industriellen Quellen. Chemie Ingenieur Technik Special Issue: ProcessNet-Jahrestagung 2014 Und 31 DECHEMA-Jahrestagung Der Biotechnologen 2014;86:1430-1.

[204] Biegger P, Felder AH, Lehner M. Methan als Speicher für erneuerbare Energien und zur CO2-Verwertung. DepoTech 2014 - Abfallwirtschaft, Abfallverwertung und Recycling, Deponietechnik und Altlasten, 2014.

[205] Steinmüller H. Power-to-Gas Umsetzung in Österreich. Jahreskonferenz Power to Gas - eine Syst. auf dem Weg zur Marktreife , 2013.

[206] OptFuel - Optimization of energy carrier production from biomass by using excess energy 2015. http://www.vt.tuwien.ac.at/thermal_process_engineering_and_simulation/comput ational_fluid_dynamics/projects/current_projects/optfuel_optimization_of_energ y_carrier_production_from_biomass_by_using_excess_energy/EN/ (accessed January 21, 2016).

[207] Biegger P, Felder AH, Lehner M. Methanisierung von CO2 als chemischer Energiespeicher. Proceedings of the 10th Minisymposium Verfahrenstechnik, 2014.

[208] Lindorfer J. Ökologische Prozessbewertung und die Anwendung in aktuellen Forschungsprojekten. Bioenergy Day, 2014.

[209] Reed J. Hydrogen Energy Storage Activities. DOE Hydrogen and Fuel Cell Technical Advisory Committee Meeting, Southern California Gas Company; 2015.

[210] Rasberry T. Southern California Gas Comments on Draft AB 1257 Report (Docket No. 15-IEPR-04). SoCalGas; 2015.

[211] Cabalzar U. Projekt: Renerg2 / Future Mobility Demonstrator. Expert. IET, Hochschule für Technik Rapperswil; 2014.

[212] Gassmann F, Lutz P, Elber U. Annual Activity Report 2014. Competence Center Energy and Mobility CCEM; 2014.

[213] RENERG2 - RENewable enERgies in future energy supply 2015. https://www.zhaw.ch/de/forschung/personen-publikationenprojekte/detailansicht-projekt/projekt/1754/ (accessed December 11, 2015).

[214] Schildhauer T. Die Energy System Integration Platform am PSI. Expert. (13.02.2015), IET, 2015.

[215] Borgschulte A, Gallandat N, Probst B, Suter R, Callini E, Ferri D, et al. Sorption enhanced CO2 methanation. Phys Chem Chem Phys 2013;15:9620-5.

[216] Borgschulte A, Callini E, Stadie N, Arroyo Y, Rossell MD, Erni R, et al. Manipulating the reaction path of the $\mathrm{CO} 2$ hydrogenation reaction in molecular sieves. Catal Sci Technol 2015;5:4613-21.

[217] SmartCat - Swiss Federal Office of Energy SFOE Ongoing projects 2015. http://www.bfe.admin.ch/forschungbiomasse/02390/02719/06391/index.html (accessed November 17, 2015).

[218] Catalytic methanation of industrially-derived CO2 (Project 153928), SNSF P3 Research Database 2015. http://p3.snf.ch/project-153928 (accessed November 17, 2015). 
[219] Projekt SmartCat, Upgrade für Biogas - Erdgas 2015. http://www.erdgas.ch/erdgas/forschung-und-entwicklung/strom-erzeugendeheizung/upgrade-fuer-biogas/ (accessed November 17, 2015).

[220] Heel A. Joint Project: CO2 Reduction \& Reuse - Renewable Fuels for Efficient Electricity Production. NRP 70 Energy Turnaround and NRP 71 Managing Energy Consumption - Kick-off Meeting, Luzern: IMPE - Institute of Materials and Process Engineering; 2015.

[221] Graf P. Power to Gas in der Schweiz. Medienreise Power to Gas-Anlage von Audi in Werlte vom 27. Mai 2014, 2014.

[222] Müller K, Beinlich N, Rachow F, Israel J, Schwiertz C, Charlafti E, et al. Methanation of recovered oxyfuel-CO2 from Ketzin and of flue gas emitted by conventional power plants. European Geosciences Union - General Assembly, Vienna, Austria: 2015.

[223] CO2-Methanation of flue gas $2015 . \quad$ http://www.tucottbus.de/fakultaet1/en/applied-physics-and-

sensors/research/projekte/aktuell/flue-gas-methanation.html (accessed December 1, 2015).

[224] Israel J, Rachow F, Müller K, Beukert G, Schmeiber D. Upscaling of catalytic CO2 methanation to a demonstration plant. International GeoEn Conference 2012, 2012.

[225] Müller K, Israel J, Rachow F, Fleige M, Städter M, Schmeißer D. Methanation of $\mathrm{CO} 2$ the power to gas approach. Cluster-to-Cluster Exchange at BTU CottbusSenftenberg, 2013.

[226] Drucksache 18/2448 - Antwort der Bundesregierung auf die Kleine Anfrage der Abgeordneten Annalena Baerbock, Oliver Krischer, Bärbel Höhn, weiterer Abgeordneter und der Fraktion BÜNDNIS 90/DIE GRÜNEN. Deutscher Bundestag; 2014.

[227] Müller K, Rachow F, Israel J, Schmeiber D. Sabatier based CO2-Methanation under oxyfuel conditions. EMRS Spring Meeting, Symposium Z Materials development for solar fuel production and energy conversion, Lille, France: 2014.

[228] Müller K, Städter M, Rachow F, Hoffmannbeck D, Schmeiber D. Sabatier-based CO2-methanation by catalytic conversion. Environ Earth Sci 2013;70:3771-8.

[229] Müller K, Fleige M, Rachow F, Schmeiber D. Sabatier based CO2-methanation of flue gas emitted by conventional power plants. Energy Procedia 2013;40:2408.

[230] CO2 catalysis, pilot plant (Technikum, 2, Upgrade) 2015. http://www.tucottbus.de/fakultaet1/en/applied-physics-andsensors/research/projekte/abgeschlossen/co2-catalysis-technikum-2.html (accessed December 10, 2015).

[231] EFRE-Begünstigtenliste 2014. Ministerium für Wirtschaft und Energie; 2015.

[232] Duyar MS, Treviño MAA, Farrauto RJ. Dual function materials for CO2 capture and conversion using renewable H2. Appl Catal B Environ 2015;168:370-6.

[233] Janke C, Duyar MS, Hoskins M, Farrauto R. Catalytic and adsorption studies for the hydrogenation of CO2 to methane. Appl Catal B Environ 2014;152-153:18491.

[234] Duyar MS, Ramachandran A, Wang C, Farrauto RJ. Kinetics of CO2 methanation over $\mathrm{Ru} / \gamma$-Al2O3 and implications for renewable energy storage 
applications. J CO2 Util 2015;12:27-33.

[235] Burkhardt M, Koschack T, Busch G. Biocatalytic methanation of hydrogen and carbon dioxide in an anaerobic three-phase system. Bioresour Technol 2015;178:330-3.

[236] Burkhardt M, Busch G. Methanation of hydrogen and carbon dioxide. Appl Energy 2013;111:74-9. 


\section{List of tables}

Table 1: Summary of selected reviews of renewable energy and $\mathrm{CO}_{2}$ hybrid storage techniques (2010 onwards).

Table 2: Summary of 3step-Power to Gas projects.

Table 3. Technical parameters comparison of PtG projects with catalytic methanation.

Table 4. Technical parameters comparison of PtG projects with biological methanation.

\section{List of figures}

Figure 1: Renewable energy and $\mathrm{CO}_{2}$ hybrid storage techniques.

Figure 2. Existing PtG projects distributed by country and technology.

Figure 3. Timeline of worldwide existing PtG projects. 